\title{
Effect of Postruminal Glutamine Supplementation on Immune Response and Milk Production in Dairy Cows
}

\author{
L. Doepel, ${ }^{* 1}$ M. Lessard,† N. Gagnon, † G. E. Lobley,‡ J. F. Bernier, ${ }^{\star}$ P. Dubreuil,§ and H. Lapierre $\dagger^{2}$ \\ *Département des Sciences Animales, Université Laval, Ste-Foy, Quebec, Canada, G1K 7P4 \\ †Dairy and Swine Research and Development Centre, Agriculture and Agri-Food Canada, Lennoxville, \\ Quebec, Canada, J1M 1 Z3 \\ ‡Rowett Research Institute, Aberdeen, UK AB21 9SB \\ §Faculté de Médecine Vétérinaire, Université de Montréal, St. Hyacinthe, Quebec, Canada, J2S 7C6
}

\begin{abstract}
Seventeen multiparous Holstein cows were used to examine the effect of an increased duodenal supply of Gln on immune function and production. Cows received continuous abomasal infusions of water (control: $\mathrm{n}=8$ ) or $300 \mathrm{~g} / \mathrm{d}$ of Gln ( $=9$ ) for $21 \mathrm{~d}$ starting within $48 \mathrm{~h}$ of calving. There were nonsignificant increases in milk and milk protein yields in response to Gln supplementation. Glutamine treatment had no effect on plasma glucose, nonesterified fatty acids (NEFA), or $\beta$-hydroxybutyrate (BHBA) concentrations but did tend to increase plasma urea $\mathrm{N}$ concentration. The Gln treatment resulted in an increase of $108 \mu M$ in the plasma Gln concentration. Total essential AA concentrations decreased with the Gln treatment, whereas total nonessential AA concentrations were unaffected. T Lymphocyte proliferation did not differ between the control and Gln-treated cows. Treatment had no effect on the relative abundance of CD8 $\mathrm{T}$ cells but did increase the abundance of CD4 T cells. Cytokine production, as measured by IFN- $\gamma$ concentration determined in vitro in concanavalin-A-stimulated peripheral blood mononuclear cells, was similar between the treatments. Over the first $3 \mathrm{wk}$ following calving, Gln supplementation had limited effects on milk production, metabolic parameters, and immune function.
\end{abstract}

Key words: glutamine supplementation, immune response, transition cow, amino acid

\section{INTRODUCTION}

Although mammals can synthesize nonessential AA (NEAA) from other metabolic precursors, this capacity may be inadequate to meet metabolic demands under

\footnotetext{
Received October 12, 2005.

Accepted March 2, 2006.

${ }^{1}$ Current address: Department of Agricultural, Food and Nutritional Science, University of Alberta, Edmonton, Alberta, Canada, T6G 2P5.

${ }^{2}$ Corresponding author: lapierreh@agr.gc.ca
}

specific physiological or developmental conditions. To meet such extra demands, an additional dietary or exogenous supply is required, and under such conditions, the specific NEAA is classified as "conditionally essential." Examples include Gly, which is beneficial for newborn infants and nursing mothers (Jackson, 1991), and Pro and Arg, which enhance piglet performance (Brunton et al., 1999). Similarly, during periods of physiological stress such as trauma, burns, and postoperative recovery, supplemental Gln has proven beneficial (Lacey and Wilmore, 1990). Indeed, Gln is one of the most versatile AA in terms of metabolic uses. Notably, the immune system requires a Gln supply for lymphocyte proliferation (Newsholme, 2001) and cytokine production (Chang et al., 1999). Glutamine also acts as a precursor for purine and pyrimidine synthesis, particularly in the intestinal tract and tissues of the immune system (Gate et al., 1999) or in tissues that undergo rapid growth, such as the mammary gland at initiation of lactation. Furthermore, in porcine intestinal cells, Gln and Glu are major energy sources, contributing nearly 10-fold more to $\mathrm{CO}_{2}$ production than does glucose (Reeds et al., 2000). In addition to these roles, milk protein synthesis also represents an important requirement because Gln and Glu constitute approximately $20 \%$ of casein (Eigel et al., 1984).

Metabolic demands for Gln may be especially high in the early postpartum cow, when the demands for milk protein synthesis are accompanied by a major increase in intestinal and mammary gland mass and activity and whole body energy expenditure. During this period, the intestine may increase its reliance on Gln as an energy source to spare glucose. Additionally, there is a deficiency of propionate to meet glucose demands, and the body must therefore rely on other gluconeogenic precursors. As a result, there may be enhanced conversion of Gln to glucose in an attempt to help satisfy demand. Such competing demands for Gln are evidenced by the lengthy depression in postcalving plasma Gln concentration. Although plasma concentrations of most AA are depressed immediately following calving, 
these are usually restored within 2 to $4 \mathrm{wk}$. This is not the case for Gln, where the lowered concentration persists for much longer (Meijer et al., 1995a; Doepel et al., 2002). This suggests that the combination of dietary supply and synthesis de novo are insufficient to meet metabolic demands, and this may result in other processes becoming compromised. This may include immune system function, and indeed immunosuppression is often experienced by the periparturient cow (Goff and Horst, 1997).

By overcoming the limitation on Gln supply, the postpartum cow could increase milk production and improve immune status. Such benefits would arise first through provision of an alternative energy supply to the gut, thus increasing glucose availability to the mammary gland, and second by increasing the arterial supply of Gln to the mammary gland and immune system. These concepts were examined in the current study, where Gln was supplemented for 3 wk immediately after parturition.

\section{MATERIALS AND METHODS}

\section{Animals and Treatments}

Twenty multiparous Holstein cows averaging $710 \pm$ $62 \mathrm{~kg}$ of BW 4 wk before expected calving were housed in tie stalls in a heated barn (approximately $15^{\circ} \mathrm{C}$ ). Twelve of the cows were surgically implanted with abomasal catheters during the dry period (mean of $31 \mathrm{~d}$ precalving). The remaining 8 cows were surgically implanted with chronic indwelling catheters in the mesenteric, portal, and hepatic veins (Huntington et al., 1989) in addition to the abomasal catheters. For these cows, surgeries were performed a minimum of $6 \mathrm{wk}$ before calving. These cows were used in a continuation of the present study to determine the effect of Gln on nutrient splanchnic flux, and the results will be reported in a future publication. Of the cows with abomasal catheters only, one developed severe mastitis precalving and was removed from the study prior to its inception. The catheter of a second cow became displaced during her infusion; thus, she was removed from the study. One of the 8 cows with the splanchnic catheters developed an ulcerated cecum and subsequently was euthanized. Thus, 17 cows were used in the study.

The abomasal catheterization was performed as follows. Cows were fasted for $24 \mathrm{~h}$ prior to surgery. One hour before surgery, $3 \mathrm{mg} / \mathrm{kg}$ of ketoprofen (Anafen; Merial, Quebec, Canada) and $20 \mathrm{mg}$ of acepromazine maleate (Atravet; Ayerst Laboratories, Guelph, Ontario, Canada) were injected intravenously. Cows then received paravertebral anesthesia of the right flank using lidocaine $\mathrm{HCl} 2 \%$ (Ayerst Laboratories), and the flank was prepared for laparotomy. A 15-cm-long right- flank incision was made 7 to $8 \mathrm{~cm}$ caudal and parallel to the 13th rib, starting $20 \mathrm{~cm}$ under the edge of the transverse process of the vertebra. The skin, the external and internal abdominal oblique, and the transverse muscles as well as the peritoneum were incised to expose the abdominal organs. The pyloric portion of the abomasum was exteriorized and an $8 \mathrm{G}$ needle was inserted through the parietal surface of the abomasal wall into the lumen $\sim 15 \mathrm{~cm}$ cranial to the pylorus. Ten centimeters of $14 \mathrm{G}$ Tygon tubing was inserted via the needle in the abomasum. The needle was withdrawn and a purse-string suture was made around the tubing exteriorization. The tubing was sutured to the parietal surface of the abomasum and exteriorized through the dorsal surface of the cow. Thereafter, a standard omentopexy was performed.

Cows were blocked by parity, expected calving date, and previous milk production and were randomly assigned within block to 1 of 2 abomasal infusions: $10 \mathrm{~L} / \mathrm{d}$ of water (control; $\mathrm{n}=8$, includes 3 cows with splanchnic catheters) or $300 \mathrm{~g} / \mathrm{d}$ of L-Gln delivered in $10 \mathrm{~L}$ of water (Gln; $\mathrm{n}=9$, includes 4 cows with splanchnic catheters). Infusions were initiated within $48 \mathrm{~h}$ following parturition and were administered continuously for $21 \mathrm{~d}$ via a peristaltic pump. Although nutrient demands increase in the close-up dry period because of fetal growth and mammogenesis, treatments were not initiated precalving because nutrient demands are 3 - to 4 -fold higher postcalving, making a response to treatment more likely at that time. Additionally, the cows were placed in maternity pens from $5 \mathrm{~d}$ precalving to several hours postcalving, making it impossible to maintain an infusion line during the immediate peripartum period. Fresh L-Gln infusion solutions were prepared daily.

For 4 wk preceding calving, cows were fed a close-up TMR once daily at $0800 \mathrm{~h}$ (Table 1 ). Cows also received $2 \mathrm{~kg} / \mathrm{d}$ of long grass hay $(9.6 \% \mathrm{CP}, 36.1 \% \mathrm{ADF}, 60.6 \%$ NDF). After calving, a lactating cow TMR was fed twice daily at 0800 and $1600 \mathrm{~h}$ (Table 1 ). The cows also received $20 \mathrm{~g}$ of rumen-protected Met (Mepron; Degussa, Düsseldorf, Germany) once daily. This was mixed in a small amount of corn grain $(\sim 200 \mathrm{~g})$ and given immediately before the morning feeding. Two kilograms per day of long alfalfa hay $(11.9 \% \mathrm{CP}, 32.9 \% \mathrm{ADF}, 56.1 \%$ $\mathrm{NDF}$ ) was also fed in the morning before the TMR was offered. During both the pre- and postpartum periods, the TMR were offered ad libitum. Moisture content of the silages was determined weekly and used to make ration adjustments. Orts were recorded daily. Cows were given free access to fresh water. Cows were milked twice a day, at 0830 and $1930 \mathrm{~h}$, and milk yield was recorded at each milking.

The experimental protocol was approved by the Institutional Committee for Animal Care of the Lennoxville 
Table 1. Ingredient and nutrient composition of pre- and postcalving diets

\begin{tabular}{|c|c|c|}
\hline Composition & Precalving & Postcalving \\
\hline \multirow{2}{*}{\multicolumn{3}{|c|}{ Ingredient }} \\
\hline & & \\
\hline Corn silage & 42.3 & 38.2 \\
\hline Grass hay ${ }^{1}$ & 16.8 & 19.8 \\
\hline High-moisture corn & 13.9 & 19.0 \\
\hline Beet pulp & 12.8 & - \\
\hline Soybean meal & 6.0 & 11.1 \\
\hline Protein supplement $^{2}$ & 6.0 & - \\
\hline Rumen bypass soybean meal ${ }^{3}$ & - & 6.7 \\
\hline Mineral and vitamin premix ${ }^{4}$ & 1.4 & 3.2 \\
\hline Rumen bypass fat ${ }^{5}$ & - & 1.2 \\
\hline Limestone & 0.9 & 0.7 \\
\hline \multicolumn{3}{|l|}{ Chemical } \\
\hline $\mathrm{DM}$ & 49.8 & 45.9 \\
\hline $\mathrm{CP}$ & 14.1 & 16.8 \\
\hline $\mathrm{ADIP}^{6}$ & 0.94 & 0.82 \\
\hline $\mathrm{ADF}$ & 20.8 & 17.5 \\
\hline $\mathrm{NDF}$ & 33.5 & 28.6 \\
\hline Ether extract & 2.8 & 4.2 \\
\hline Lignin & 2.04 & 1.56 \\
\hline Ash & 6.02 & 7.57 \\
\hline $\mathrm{Ca}$ & 0.77 & 1.01 \\
\hline $\mathrm{P}$ & 0.50 & 0.57 \\
\hline $\mathrm{Mg}$ & 0.35 & 0.30 \\
\hline $\mathrm{K}$ & 1.30 & 1.50 \\
\hline $\mathrm{Na}$ & 0.16 & 0.47 \\
\hline $\mathrm{DCAD},{ }^{7} \mathrm{mEQ} / \mathrm{kg}$ & 82 & 177 \\
\hline $\mathrm{NE}_{\mathrm{L}}{ }^{8} \mathrm{Mcal} / \mathrm{kg}$ & 1.63 & 1.72 \\
\hline $\mathrm{MP},{ }^{9} \mathrm{~g} / \mathrm{d}$ & 1,255 & 1,948 \\
\hline
\end{tabular}

${ }^{1}$ Precalving hay contained $9.6 \% \mathrm{CP}$; postcalving hay contained $11.9 \% \mathrm{CP}$

${ }^{2}$ Contains $15 \%$ corn distillers' grains, $25 \%$ corn gluten meal, $20 \%$ wheat distillers' grains, 20\% Soyplus (West Central Soy, Ralston, IA), and $20 \%$ canola meal.

${ }^{3}$ Soyplus (West Central Soy).

${ }^{4}$ Precalving mineral and vitamin premix contained $3 \% \mathrm{Ca}, 11 \% \mathrm{P}$, $12 \% \mathrm{Mg}, 7 \% \mathrm{Na}, 2.3 \% \mathrm{~S}, 120 \mathrm{mg} / \mathrm{kg}$ Co, $1,610 \mathrm{mg} / \mathrm{kg} \mathrm{Cu}, 4,390 \mathrm{mg} /$ $\mathrm{kg} \mathrm{Fe}, 202 \mathrm{mg} / \mathrm{kg} \mathrm{I}, 6,550 \mathrm{mg} / \mathrm{kg} \mathrm{Mn}, 40 \mathrm{mg} / \mathrm{kg} \mathrm{Se}, 6,630 \mathrm{mg} / \mathrm{kg} \mathrm{Zn}$, $730,000 \mathrm{IU} / \mathrm{kg}$ vitamin A, 246,000 IU/kg vitamin D, and 7,560 IU/kg vitamin $\mathrm{E}$; postcalving mineral and vitamin premix contained $9.5 \%$ $\mathrm{Ca}, 5.5 \% \mathrm{P}, 3.5 \% \mathrm{Mg}, 13 \% \mathrm{Na}, 2.1 \% \mathrm{~S}, 33 \mathrm{mg} / \mathrm{kg} \mathrm{Co}, 495 \mathrm{mg} / \mathrm{kg} \mathrm{Cu}$, $2745 \mathrm{mg} / \mathrm{kg} \mathrm{Fe}, 69 \mathrm{mg} / \mathrm{kg} \mathrm{I}, 2,065 \mathrm{mg} / \mathrm{kg} \mathrm{Mn}, 20 \mathrm{mg} / \mathrm{kg}$ Se, 3,000 mg/ $\mathrm{kg} \mathrm{Zn}, 500,000 \mathrm{IU} / \mathrm{kg}$ vitamin A, 65,000 IU/kg vitamin D, and 2,600 $\mathrm{IU} / \mathrm{kg}$ vitamin $\mathrm{E}$.

${ }^{5}$ Megalac (Church \& Dwight Co., Inc., Princeton, NJ).

${ }^{6}$ Acid detergent-insoluble protein.

${ }^{7}$ Dietary cation-anion difference, calculated as $[(\% \mathrm{Na} \times 435)+(\% \mathrm{~K}$ $\times 256)]-[(\% \mathrm{Cl} \times 282)+(\% \mathrm{~S} \times 624)] ;$ National Research Council $(2001)$ estimated values used for $\mathrm{Cl}$ and $\mathrm{S}$.

${ }^{8}$ Calculated from total diet (TMR + hay): precalving based on 14 kg DMI; postcalving based on $17 \mathrm{~kg}$ DMI, estimated by the National Research Council (2001).

${ }^{9}$ Metabolizable protein intake, calculated from total diet (TMR + hay): precalving based on $14 \mathrm{~kg}$ DMI; postcalving based on $17 \mathrm{~kg}$ DMI, estimated by the National Research Council (2001).

Research Center, and animals were cared for in accordance with the guidelines of the Canadian Council on Animal Care (1993).

\section{Sampling}

All diet ingredients, with the exception of the silage, were sampled weekly and composited every $4 \mathrm{wk}$; silage was composited biweekly. Milk was sampled at each milking from d 19 to 21 , and aliquots were stored at $-20^{\circ} \mathrm{C}$.

Jugular blood samples were obtained before the morning feeding on $\mathrm{d}-25,-12,-3,1,4,11$, and 18 relative to calving. Treatments were initiated following the $\mathrm{d} 1$ sample. For 5 of the 10 cows that had abomasal catheters only, $d-25$ was prior to surgery, whereas for the remaining 5 cows, $\mathrm{d}-25$ was at a minimum of 10 $\mathrm{d}$ following surgery. For cows with splanchnic catheters, $\mathrm{d}-25$ was at least 3 wk following surgery. Blood for immunological assays was collected on EDTA and kept at room temperature. At the same time, one blood sample was collected without anticoagulant for preparation of heat-inactivated autologous serum (AS). For determination of peripheral blood mononuclear cell (PBMC) AA concentrations, blood was collected on heparin and kept at room temperature. Blood for all other assays was collected on heparin or EDTA and immediately placed on ice. Plasma was obtained from this blood (15 $\min , 1,800 \times g$ at $4^{\circ} \mathrm{C}$ ) and frozen at $-80^{\circ} \mathrm{C}$ until $\mathrm{AA}$ analysis or at $-20^{\circ} \mathrm{C}$ until subsequent chemical analysis for urea N, NEFA, and glucose. Deproteinized blood was used for BHBA and lactate analyses. Briefly, $1 \mathrm{~mL}$ of whole blood was mixed with $0.9 \mathrm{~mL}$ of distilled water and $0.1 \mathrm{~mL}$ of $6 \mathrm{~N}$ perchloric acid, and the mixture was stored on ice for $1 \mathrm{~h}$ before being centrifuged and the supernatant collected for subsequent analysis.

\section{Laboratory Analyses}

Feed ingredient samples (with the exception of the silage samples, which were freeze-dried) were dried in a forced-air oven at $55^{\circ} \mathrm{C}$ for $7 \mathrm{~d}$ and ground to pass a 1-mm screen. Feed $\mathrm{N}$ was determined by combustion (Nitrogen Determinator, model FP-428; Leco, St. Joseph, $\mathrm{MI}$ ), and $\mathrm{CP}$ was calculated as $\mathrm{N} \times 6.25$. Acid detergent fiber, NDF, lignin, and acid detergent insoluble protein were determined using an Ankom 200 fiber analyzer (Ankom Technology, Macedon, NY). Ash determination was as described by AOAC (1996).

Milk $\mathrm{N}$ content (protein $=\mathrm{N} \times 6.38$ ) was determined by combustion (Nitrogen Determinator, model FP-428; Leco), and milk fat was measured according to the Röse-Gottlieb method (AOAC, 1996). Casein content was determined on pooled samples as described by Raggio et al. (2004).

Plasma AA were measured by isotope-dilution gas chromatography-mass spectrometry (Calder et al., 1999; Raggio et al., 2004). In brief, on the day of sampling, $1 \mathrm{~g}$ of plasma was added to $0.2 \mathrm{~g}$ of an internal 
standard solution and then frozen at $-80^{\circ} \mathrm{C}$ until analysis. On the day of analysis, plasma was deproteinized and AA concentrations were determined by gas chromatography-mass spectrometry (model HP6890, S973 mass selective detector; Hewlett-Packard, Palo Alto, CA).

Plasma NEFA were determined colorimetrically (NEFA-C kit, Wako Chemicals USA Inc., Richmond, VA) with the modifications of Johnson and Peters (1993). $\beta$-Hydroxybutyrate concentrations were determined by the procedure of Williamson and Mellanby (1974) adapted to a 96-well plate format. A colorimetric assay (Boehringer Mannheim, Dorval, Quebec, Canada) was used to determine glucose concentration (glucose oxidase/peroxidase). Plasma urea $\mathrm{N}$ concentrations were measured with an automatic analyzer (Technicon Autoanalyser II, Technicon Instruments Corporation, Tarrytown, NY) as previously described (Huntington, 1984). A spectrophotometric method using lactate dehydrogenase was used to measure L-lactate (Benson et al., 2002). Total leukocyte counts were determined manually using the Unopette system and a hemacytometer, and differential leukocyte counts were performed on blood smears prepared with Wright's stain.

Peripheral blood mononuclear cells were isolated from whole blood as described by Lessard et al. (2004). Briefly, blood was layered on Ficoll-Hypaque Plus (Amersham Pharmacia, Montreal, Quebec, Canada), and following centrifugation $(400 \times g$ for $40 \mathrm{~min}$ ), PBMC were collected at the interface. The cells were washed twice with Hanks' balanced salt solution without $\mathrm{Ca}^{2+}$ and $\mathrm{Mg}^{2+}$ (wash solution; Gibco BRL, Toronto, Ontario, Canada) and resuspended in RPMI 1640 medium without Gln (Gibco BRL). The number of viable cells was determined by trypan blue exclusion.

To determine the proliferative response to concanavalin A (ConA; Sigma, St. Louis, MO), isolated PBMC were diluted to $2.5 \times 10^{6}$ cells $/ \mathrm{mL}$ and $50 \mu \mathrm{L} /$ well was plated into 96 -well microtiter plates. To each well was added $100 \mu \mathrm{L}$ of RPMI 1640 without Gln. The cells were supplemented with $5 \% \mathrm{AS}$ and ConA at $0,0.125,0.5$, and $1.0 \mu \mathrm{g} / \mathrm{mL}$, or with $5 \%$ fetal bovine serum (FBS; Gibco BRL) and ConA at 0, 0.06, 0.125, and $0.5 \mu \mathrm{g} / \mathrm{mL}$. Each combination of serum and ConA was plated in triplicate. Concentrations of ConA were previously determined by Lessard et al. (2004). Plates were incubated in $5 \% \mathrm{CO}_{2}$ at $37^{\circ} \mathrm{C}$ for $72 \mathrm{~h} ; 50 \mu \mathrm{L}$ of 5 -bromo-2deoxyuridine solution was then added (Roche Diagnostics, Laval, Quebec, Canada), and the plates were incubated for another $16 \mathrm{~h}$. Cell proliferation was quantified by measuring absorbance at $370 \mathrm{~nm}$. Quantification was based on the measurement of incorporation of 5bromo-2-deoxyuridine during DNA synthesis using an anti-5-bromo-2-deoxyuridine conjugate with peroxi- dase. Absorbance was directly correlated with the amount of DNA synthesis, and thus the proliferative response of PBMC. Values are expressed as optical density units.

Characterization of blood lymphocyte populations was performed by flow cytometry analysis using the following mouse monoclonal antibodies to bovine cell surface markers: anti-CD2 (BAQ95A), anti-CD4 (ILA11), anti-CD8 (CACT80C), anti-B cells (LCT-2A), and anti- $\gamma-\delta$ T-cells (GB21A). All antibodies were purchased from VMRD (Pullman, WA). Ice-cold PBS, containing BSA at $0.5 \%$, was used to dilute antibodies and to wash the plates. All cell-labeling steps were done on ice, and all centrifugations were performed at $10^{\circ} \mathrm{C}$. Isolated PBMC were resuspended in PBS-BSA and a total of 1 $\times 10^{6}$ cells per well were plated in duplicate into 96well U-bottomed microtiter plates (Fisher Scientific, Pittsburgh, PA). Fluorescein isothiocyanate-conjugated goat antimouse $\mathrm{IgG}_{2 \mathrm{a} / 2 \mathrm{~b}}$ and the phycoerythrine-conjugated goat antimouse $\mathrm{IgG}_{1}$ (BD Pharmingen, San Diego, CA) were used as secondary antibodies for fluorescent staining. Single labeling was performed by incubating PBMC with $50 \mu \mathrm{L}$ of the specific antibody at 2.5 $\mu \mathrm{g} / \mathrm{mL}$ for $20 \mathrm{~min}$, followed by 2 washes. The cells were then labeled with $50 \mu \mathrm{L}$ of the secondary antibody at $2.5 \mu \mathrm{g} / \mathrm{mL}$, followed by 2 washes. Double-labeling was performed as follows to characterize CD4 and CD8 cell populations: PBMC were simultaneously incubated with $25 \mu \mathrm{L}$ of anti-CD4 at $5 \mu \mathrm{g} / \mathrm{mL}$ and $25 \mu \mathrm{L}$ of antiCD8 at $5 \mu \mathrm{g} / \mathrm{mL}$ for $20 \mathrm{~min}$ and washed twice. Thereafter, $25 \mu \mathrm{L}$ of each secondary antibody at $5 \mu \mathrm{g} / \mathrm{mL}$ was added for the labeling of cells. The PBMC were resuspended in PBS supplemented with $2 \%$ paraformaldehyde and analyzed on a Coulter Epics XL-MCL flow cytometer using Expo 32 software (Beckman Coulter, Mississauga, Ontario, Canada). Lymphocytes were gated by using forward and side light-scattering, and data were collected for 5,000 events. Background fluorescence was determined by labeling cells with secondary antibodies only. Immunofluorescence was expressed as the percentage of positive cells minus controls. The monocytes were also gated by using forward and side light-scattering, and the percentage of monocytes in PBMC samples was established as follows: (number of monocytes gated)/(number of lymphocytes gated + number of monocytes gated) $\cdot 100$. Interferon- $\gamma$ concentrations were determined from the supernatants of PBMC that were cultured in RPMI 1640, ConA, and AS or FBS as described by Lessard et al. (2004). Concentrations are expressed in picograms per milliliter.

The lysis and subsequent analysis of free AA concentrations in the isolated PBMC were based on the method of Fukuda et al. (1982). To a known volume and density of cells, $200 \mu \mathrm{L}$ of L-norleucine was added 
as a standard. Cells were then lysed using ultrasonic disruption. The cell lysate was deproteinized, and the protein-free supernatant was analyzed for AA concentrations by gas chromatography-mass spectrometry as described by McNeil (2001).

\section{Statistical Analysis}

Before statistical analysis, daily DMI and milk yield data for the duration of the experiment were first averaged over 2 periods per week. For example, data for $d$ 4 is the average of $d 1$ to 4 , and data for $d 7$ is the average of $\mathrm{d} 5$ to 7 .

For lymphocyte proliferation, the baseline response at $\mathrm{ConA}=0$ was subtracted from each of the values at each level of ConA before the data were subjected to statistical analysis. The data for IFN- $\gamma$ for PBMC incubated in FBS were log transformed prior to statistical analysis because the data were not normally distributed.

Repeated-measures data were analyzed using the MIXED procedure of SAS (SAS Institute, 1999). The statistical model included day, treatment (trt), and the day $\times$ trt interaction. For each analyzed variable, cow was subjected to 3 covariance structures: autoregressive order 1 , compound symmetry, and spatial power law. The covariance structure that resulted in the smallest Bayesian information criterion was used (Littell et al., 1996). Preplanned contrasts were used to determine the effects of time, treatment, and their interaction. For variables measured pre- and postpartum, a "pre vs. post" contrast compared the precalving to the postcalving treatment data. Data from d 1 were excluded from this comparison because they were postcalving but prior to treatment. A contrast "precalving vs. $d$ 1" determined the effect of parturition. Treatment effect was tested by the contrast describing the interaction of treatment by time [i.e., "trt $\times$ (pre vs. post)"]; the presence of an interaction indicated a treatment effect. Linear and quadratic effects of time were also tested for the treatment periods as well as the interactions "trt $\times$ time (linear and quadratic)." A significant interaction denoted that during the treatment period, the pattern over time was different between the control and Gln cows.

Daily milk yield and milk composition data from the last $7 \mathrm{~d}$ of treatment were reduced to weekly means prior to statistical analysis. The MIXED procedure of SAS was used (SAS Institute, 1999), with treatment considered a fixed effect and block a random effect. All data are reported as least squares means with pooled standard errors, and significance was declared at $P$ $<0.05$.

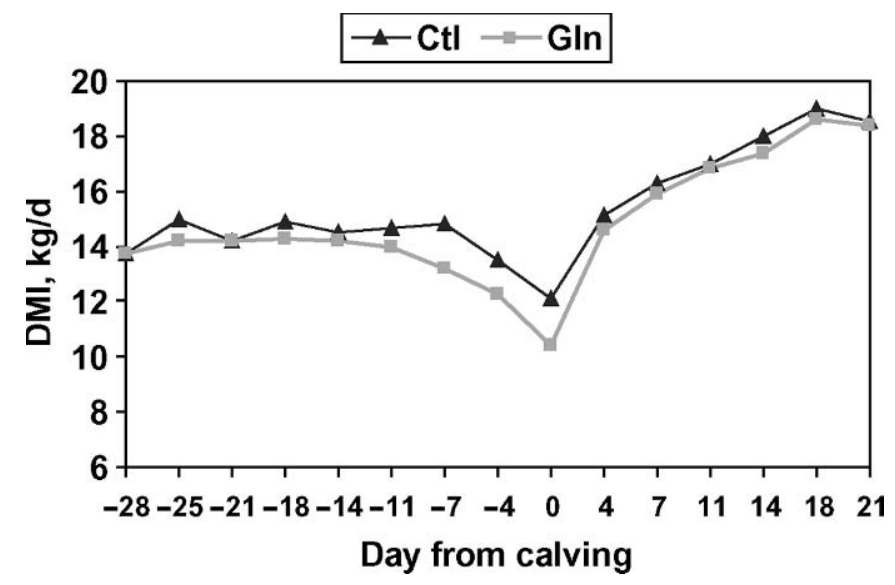

Figure 1. Dry matter intake (pooled SEM = 0.82). There were no treatment effects [trt $\times$ (pre vs. post), $P=0.79$ ]. There was a precalving $\times$ calving day interaction $(P<0.001)$ and a linear effect during the treatment period $(P<0.001)$. Cows were abomasally infused with water (control, Ctl) or $300 \mathrm{~g} / \mathrm{d}$ of Gln for $21 \mathrm{~d}$ starting within $48 \mathrm{~h}$ of calving. The data for day represent the average of 3- or 4-d periods, whereas the data for calving (d 0) were obtained from the day of calving only.

\section{RESULTS}

\section{DMI and Milk Yield}

Dry matter intake did not differ between the 2 treatments $(P=0.79)$, averaging $17.1 \mathrm{~kg} / \mathrm{d}$ during the treatment period (Figure 1, Table 2). Intake declined steadily during the precalving period, with the lowest intake observed on the day of calving (pre vs. d $1 ; P<0.001$ ). Milk yield during the entire experimental period (Figure 2) was unaffected by treatment, but there was a treatment $\times$ day interaction $(P=0.02)$, primarily because of the numerical changes between the control and Gln disappearing on d 11. Milk yield and milk component yield during the final $7 \mathrm{~d}$ of the experimental period were also not significantly different between the treatments, although there was a $1.9 \mathrm{~kg} / \mathrm{d}$ increase in milk yield and a $57 \mathrm{~g} / \mathrm{d}$ increase in milk protein yield in the Gln-treated cows (Table 2). Treatment had no effect on milk protein concentration, milk casein as a percentage of $\mathrm{CP}$, or milk fat concentration (Table 2).

\section{Metabolic Parameters}

The abomasal infusion of Gln was successful in generating an increase in plasma Gln concentration relative to the control treatment (Table 3). Concentrations during the treatment period averaged $227.6 \pm 12.19 \mu M$ for the control cows and $352.6 \pm 11.65 \mu M(P<0.001)$ for the Gln-treated cows, whereas during the precalving period, concentrations averaged 307.8 $\pm 13.38 \mu M$ and 
Table 2. DMI for the duration of the experiment, and milk production for the last $7 \mathrm{~d}$ of treatment ${ }^{1}$

\begin{tabular}{lcccc}
\hline & \multicolumn{2}{c}{ Treatment } & & \\
\cline { 2 - 3 } Item & Control & Gln & SEM & $P^{2}$ \\
\hline DMI, kg/d & & & & \\
Precalving & 14.4 & 13.8 & 0.57 & \\
Calving & 12.1 & 10.4 & 0.80 & \\
Postcalving & 17.3 & 17.0 & 0.60 & 0.79 \\
Yield & & & & \\
Milk, kg/d & 39.3 & 41.2 & 1.91 & 0.49 \\
CP, g/d & 1,212 & 1,269 & 56.8 & 0.49 \\
Casein, g/d & 976 & 1,019 & 45.0 & 0.52 \\
Fat, g/d & 1,534 & 1,508 & 89.2 & 0.79 \\
Milk composition & & & & \\
CP, \% & 3.09 & 3.08 & 0.067 & 0.90 \\
Casein, \% of CP & 80.9 & 80.3 & 0.91 & 0.48 \\
Fat, \% & 3.92 & 3.74 & 0.167 & 0.46 \\
\hline
\end{tabular}

${ }^{1} \mathrm{LSM}$ are presented with the pooled SEM.

${ }^{2}$ For DMI, $P$ value is for treatment $\times$ (pre vs. post); for all other data, $P$ value is for treatment.

$324.6 \pm 12.67 \mu M$ for the control and Gln cows, respectively.

Overall, Gln decreased $(P<0.05)$ concentrations of total essential AA (EAA), with an interaction [trt $\times$ (pre vs. post), $P<0.10$ ] for the following individual EAA: Leu, Met, Phe, Thr, and Val. Concentrations of His, Ile, Lys, and Trp were unaffected by Gln infusion. Total NEAA (excluding Gln) concentrations were unaffected $(P=0.21)$ by treatment, but for Gly $(P=0.05)$, Ser $(P=$ $0.03)$, and Tyr $(P=0.04)$, there was a trt $\times$ time-linear post interaction. For the control cows, Gly and Tyr concentrations increased from $\mathrm{d} 4$ to 18 , whereas for the Gln cows they remained constant during the same time period. In contrast, Ser concentrations in the control

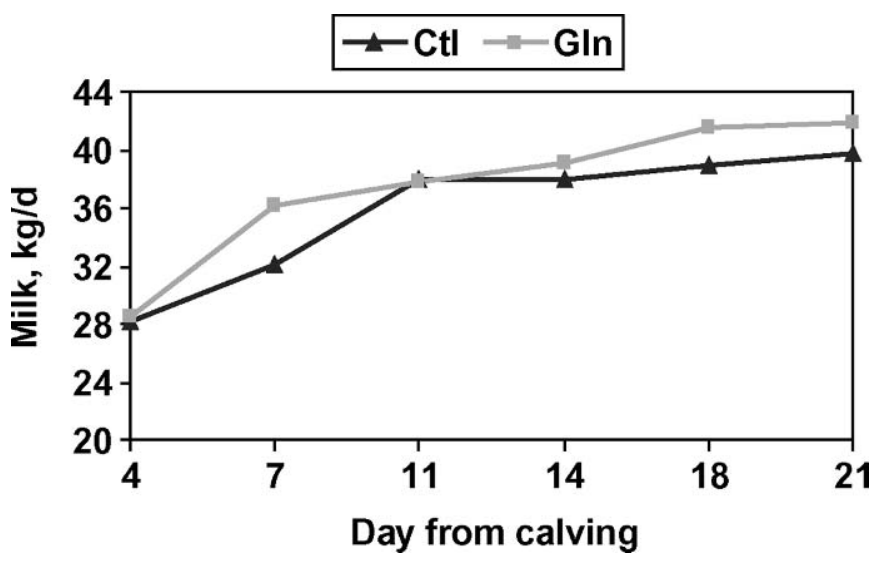

Figure 2. Milk yield during the entire treatment period (pooled SEM $=1.93)$. There was a treatment $\times$ day effect $(P=0.02)$. Cows were abomasally infused with water (control, Ctl) or $300 \mathrm{~g} / \mathrm{d}$ of Gln for $21 \mathrm{~d}$ starting within $48 \mathrm{~h}$ of calving. The data for day represent the average of 3 - or 4 -d periods. cows remained constant during the treatment period but decreased for the Gln cows. The overall effect of Gln relative to control was a reduction in total AA plasma concentrations $(P=0.09)$

Plasma concentrations of most AA decreased at calving (pre vs. $\mathrm{d} 1, P<0.05$; Table 3 ). The exceptions were Met and Ser, whose concentrations did not change, and Gly, which showed an increase. Relative to precalving, concentrations of His and Phe were lower $(P<0.01)$ postcalving and remained constant. Concentrations of Lys were also lower postcalving but increased over time, whereas concentrations of Ile were higher post- vs. precalving $(P<0.01)$. With the exception of Gly, concentrations of NEAA were all lower $(P<0.01)$ postcalving vs. precalving.

Plasma urea $\mathrm{N}$ concentrations (Figure 3 ) of the control and Gln cows exhibited a different pattern during the precalving period (trt $\times$ linear effect precalving: $P=$ $0.02)$. On $d-25$, the control cows $(5.92 \mathrm{mM})$ had a lower urea $\mathrm{N}$ concentration than the Gln cows $(7.94 \mathrm{mM})$, but by $\mathrm{d}-12$, the concentrations were similar. Because the urea concentrations were essentially the same between the 2 treatment groups on $\mathrm{d}-12,-3$, and 1 , the data were reanalyzed excluding $\mathrm{d}-25$. Glutamine infusion tended to increase urea $\mathrm{N}$ concentrations [trt $\times$ (pre vs. post), $P=0.09$ ], averaging 9.3 and $10.7 \mathrm{~m} M$ for the control and Gln-treated cows, respectively. Calving had no influence on urea $\mathrm{N}$ concentrations (pre vs. d 1, $P=0.59$ ).

Plasma glucose concentrations are shown in Figure 4. Although there was no treatment effect [trt $\times$ (pre vs. post): $P=0.94$ ], there was a tendency for a trt $\times$ linear effect $(P=0.10)$. On $d 4$, the control cows experienced a substantial decline in concentration, whereas the Gln cows did not. Across treatments, glucose concentrations were lower (pre vs. post; $P=0.001$ ) after calving (3.04 $\mathrm{m} M \pm 0.085)$ than precalving (3.61 $\mathrm{m} M \pm 0.092)$. Unlike glucose, lactate concentrations did not differ in the 2 periods (pre vs. post, $P=0.83$; Figure 5), averaging 0.90 $\pm 0.130 \mathrm{~m} M$ in the precalving period and $0.93 \pm 0.122$ $\mathrm{m} M$ in the treatment period. However, concentration on $\mathrm{d} 1(1.35 \pm 0.155 \mathrm{mM})$ was significantly higher than precalving (pre vs. $\mathrm{d} 1, P=0.007$ ). Treatment had no effect on lactate concentrations [trt $\times$ (pre vs. post), $P=0.98]$.

Plasma NEFA (Figure 6) and BHBA (Figure 7) concentrations did not differ between treatments but did differ with physiological stage, being lower in the precalving period than the postcalving period $(P<0.03)$. Nonesterified fatty acid concentrations averaged 223.3 $\pm 88.38,1,039.8 \pm 103.93$, and $992.6 \pm 83.69 \mu M$ in the precalving period, on $\mathrm{d} 1$, and during the treatment period, respectively. Similarly, BHBA concentrations increased from $0.37 \pm 0.156 \mathrm{~m} M$ in the precalving period 
Table 3. Plasma AA concentrations $(\mu M)^{1}$

\begin{tabular}{|c|c|c|c|c|c|c|c|c|c|c|c|c|c|c|c|c|}
\hline \multirow{3}{*}{$\begin{array}{l}\text { Plasma } \\
\text { AA }\end{array}$} & \multirow[b]{3}{*}{ Trt } & \multirow{2}{*}{\multicolumn{7}{|c|}{ Day }} & \multirow[b]{3}{*}{ SEM } & \multicolumn{3}{|c|}{ Trt $\times$ time $P$} & \multicolumn{4}{|c|}{ Time $P$} \\
\hline & & & & & & & & & & \multirow{2}{*}{$\begin{array}{l}\text { Trt } \times \\
\text { (pre vs. } \\
\text { post) }\end{array}$} & \multirow{2}{*}{$\begin{array}{l}\text { Trt } \times \\
\text { lin } \\
\text { post }\end{array}$} & \multirow{2}{*}{$\begin{array}{l}\text { Trt } \times \\
\text { quad } \\
\text { post }\end{array}$} & \multirow{2}{*}{$\begin{array}{l}\text { Pre } \\
\text { vs. } \\
\text { post }\end{array}$} & \multirow{2}{*}{$\begin{array}{l}\text { Pre vs. } \\
\text { d } 1\end{array}$} & \multirow{2}{*}{$\begin{array}{l}\text { Post } \\
\text { lin }\end{array}$} & \multirow{2}{*}{$\begin{array}{l}\text { Post } \\
\text { quad }\end{array}$} \\
\hline & & -25 & -12 & -3 & 1 & 4 & 11 & 18 & & & & & & & & \\
\hline \multicolumn{17}{|l|}{$\mathrm{EAA}$} \\
\hline \multirow[t]{2}{*}{ His } & Control & 64.8 & 62.1 & 58.6 & 48.9 & 45.9 & 46.4 & 48.0 & 5.72 & 0.99 & 0.35 & 0.18 & 0.001 & 0.001 & 0.75 & 0.13 \\
\hline & Gln & 76.2 & 67.1 & 61.4 & 49.2 & 58.2 & 47.6 & 53.9 & & & & & & & & \\
\hline \multirow{2}{*}{ Ile } & Control & 108.5 & 122.4 & 101.6 & 87.5 & 124.5 & 163.9 & 181.3 & 15.62 & 0.14 & 0.92 & 0.57 & 0.001 & 0.003 & 0.001 & 0.13 \\
\hline & Gln & 123.8 & 115.6 & 113.8 & 71.9 & 100.7 & 154.6 & 160.3 & & & & & & & & \\
\hline \multirow{2}{*}{ Leu } & Control & 170.0 & 171.5 & 152.0 & 126.0 & 140.6 & 187.2 & 207.2 & 16.73 & 0.06 & 0.53 & 0.59 & 0.69 & 0.001 & 0.001 & 0.11 \\
\hline & Gln & 189.0 & 174.4 & 157.5 & 107.0 & 119.5 & 170.6 & 167.9 & & & & & & & & \\
\hline \multirow[t]{2}{*}{ Lys } & Control & 79.2 & 97.1 & 57.2 & 45.1 & 62.6 & 70.9 & 75.8 & 6.42 & 0.45 & 0.93 & 0.94 & 0.004 & 0.001 & 0.03 & 0.79 \\
\hline & Gln & 92.8 & 71.7 & 61.0 & 43.1 & 55.3 & 62.3 & 67.5 & & & & & & & & \\
\hline Met & Control & 24.8 & 27.7 & 23.4 & 24.9 & 29.7 & 28.3 & 27.6 & 1.91 & 0.09 & 0.73 & 0.87 & 0.14 & 0.35 & 0.11 & 0.68 \\
\hline & Gln & 26.9 & 25.2 & 23.3 & 22.9 & 26.8 & 24.4 & 23.6 & & & & & & & & \\
\hline Phe & Control & 52.9 & 58.4 & 52.2 & 40.6 & 46.5 & 47.5 & 50.7 & 3.25 & 0.08 & 0.50 & 0.49 & 0.001 & 0.001 & 0.49 & 0.77 \\
\hline & Gln & 51.5 & 54.3 & 49.7 & 38.6 & 37.9 & 40.5 & 37.9 & & & & & & & & \\
\hline Thr & Control & 66.8 & 73.5 & 60.9 & 57.1 & 71.2 & 81.9 & 90.8 & 7.18 & 0.004 & 0.20 & 0.60 & 0.42 & 0.001 & 0.06 & 0.73 \\
\hline & Gln & 74.2 & 67.6 & 53.0 & 37.7 & 56.4 & 53.8 & 60.3 & & & & & & & & \\
\hline Trp & Control & 48.1 & 46.9 & 33.6 & 21.7 & 28.4 & 39.9 & 47.0 & 3.54 & 0.27 & 0.12 & 0.95 & 0.001 & 0.001 & 0.001 & 0.40 \\
\hline & Gln & 47.4 & 44.8 & 37.1 & 15.4 & 29.2 & 35.8 & 38.6 & & & & & & & & \\
\hline Val & Control & 228.6 & 248.9 & 207.9 & 160.9 & 200.9 & 269.6 & 309.1 & 21.03 & 0.009 & 0.34 & 0.73 & 0.92 & 0.001 & 0.001 & 0.56 \\
\hline & Gln & 262.0 & 242.3 & 222.0 & 127.6 & 175.0 & 215.4 & 248.4 & & & & & & & & \\
\hline NEAA & & & & & & & & & & & & & & & & \\
\hline Ala & Control & 240.4 & 229.9 & 195.1 & 169.9 & 163.0 & 194.5 & 192.9 & 15.69 & 0.27 & 0.20 & 0.21 & 0.001 & 0.001 & 0.23 & 0.72 \\
\hline & Gln & 245.8 & 211.8 & 192.0 & 141.2 & 165.1 & 155.5 & 164.0 & & & & & & & & \\
\hline Cys & Control & 111.9 & 118.2 & 99.4 & 67.7 & 88.1 & 91.3 & 88.1 & 5.97 & 0.32 & 0.48 & 0.51 & 0.001 & 0.001 & 0.49 & 0.93 \\
\hline & Gln & 116.5 & 111.7 & 101.0 & 67.1 & 80.5 & 81.5 & 87.3 & & & & & & & & \\
\hline Gln & Control & 330.5 & 300.0 & 292.8 & 258.7 & 244.3 & 215.0 & 223.5 & 2.96 & 0.001 & 0.15 & 0.84 & 0.01 & 0.01 & 0.01 & 0.13 \\
\hline & Gln & 363.7 & 295.1 & 314.9 & 300.7 & 395.5 & 336.1 & 326.2 & & & & & & & & \\
\hline Glu & Control & 67.5 & 45.1 & 41.4 & 39.1 & 37.8 & 40.8 & 43.5 & 18.77 & 0.30 & 0.28 & 0.75 & 0.001 & 0.001 & 0.33 & 0.69 \\
\hline & Gln & 56.5 & 43.1 & 43.9 & 36.0 & 40.4 & 42.0 & 40.1 & & & & & & & & \\
\hline Gly & Control & 289.7 & 251.7 & 285.9 & 359.6 & 402.8 & 529.9 & 471.3 & 35.80 & 0.14 & 0.05 & 0.11 & 0.001 & 0.01 & 0.77 & 0.05 \\
\hline & Gln & 282.5 & 252.4 & 316.2 & 330.3 & 443.1 & 426.4 & 392.0 & & & & & & & & \\
\hline Ser & Control & 93.1 & 86.9 & 87.3 & 90.0 & 73.9 & 79.0 & 77.1 & 7.90 & 0.61 & 0.03 & 0.03 & 0.001 & 0.13 & 0.10 & 0.13 \\
\hline & Gln & 90.1 & 75.4 & 96.9 & 70.7 & 89.5 & 58.0 & 66.0 & & & & & & & & \\
\hline Tyr & Control & 63.7 & 60.8 & 49.1 & 38.0 & 35.8 & 43.1 & 49.1 & 3.45 & 0.04 & 0.04 & 0.54 & 0.001 & 0.001 & 0.04 & 0.71 \\
\hline & Gln & 57.8 & 52.7 & 46.8 & 33.3 & 30.3 & 27.6 & 30.2 & & & & & & & & \\
\hline Total EAA & Control & 745.0 & 696.7 & 573.8 & 610.1 & 747.5 & 935.8 & $1,037.4$ & 96.92 & 0.05 & 0.89 & 0.81 & 0.006 & 0.067 & 0.002 & 0.41 \\
\hline & Gln & 838.4 & 853.0 & 433.5 & 512.3 & 588.2 & 801.3 & 854.8 & & & & & & & & \\
\hline Total NEAA & Control & 761.3 & 587.6 & 575.0 & 764.3 & 801.4 & 978.6 & 921.9 & 86.76 & 0.21 & 0.56 & 0.52 & 0.001 & 0.24 & 0.40 & 0.35 \\
\hline & Gln & 738.1 & 747.2 & 432.2 & 678.6 & 758.8 & 790.9 & 779.5 & & & & & & & & \\
\hline Total AA & Control & $1,506.4$ & $1,284.3$ & $1,148.8$ & $1,374.4$ & $1,548.9$ & $1,914.3$ & $1,959.3$ & 172.17 & 0.09 & 0.70 & 0.83 & 0.001 & 0.72 & 0.03 & 0.35 \\
\hline & Gln & $1,576.5$ & $1,600.2$ & 865.7 & $1,190.9$ & $1,347.0$ & $1,592.2$ & $1,634.3$ & & & & & & & & \\
\hline $\begin{array}{l}{ }^{1} \mathrm{LSM} \text { are } \\
\text { honessentia }\end{array}$ & ented & he po & SEM. & tre & pr & al & & alvin & $=1$ & ffec & $=$ & $\mathrm{ra}$ & $\mathrm{t}$ & $=\mathrm{e}$ & A & $\mathrm{AA}=$ \\
\hline${ }^{2}$ Days -25, & , and - & e prec & $\mathrm{ng} ; \mathrm{d} 4$, & 1 , and 1 & post & ing val & used for & ontrast. & & & & & & & & \\
\hline
\end{tabular}




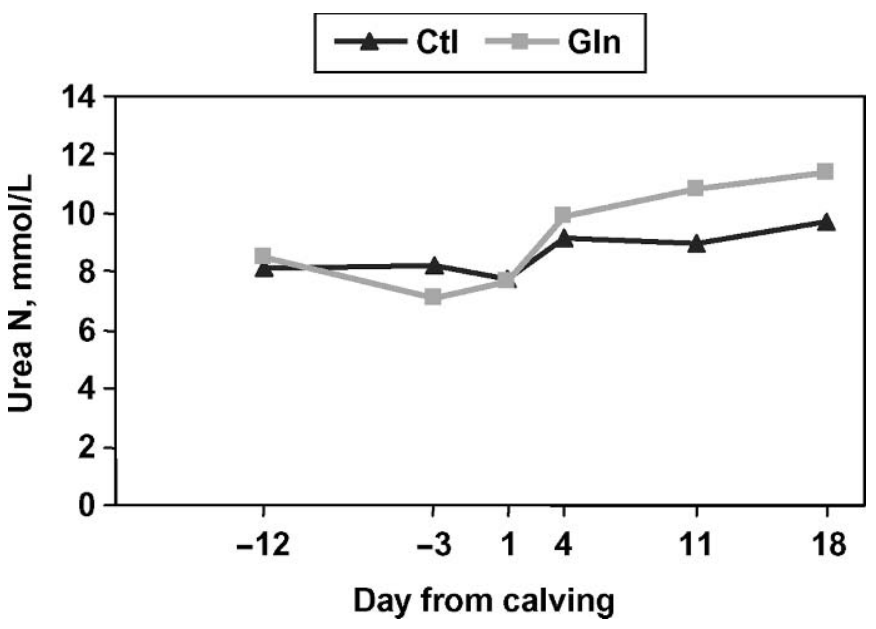

Figure 3. Plasma urea $\mathrm{N}$ concentrations (pooled SEM $=0.690$ ). Data from $d-25$ are excluded (see text for explanation). There was a tendency for a treatment effect [trt $\times$ (pre vs. post), $P=0.09$ ]. Urea $\mathrm{N}$ concentrations were lower before calving than during the treatment period (pre vs. post; $P<0.001$ ). Cows were abomasally infused with water (control, Ctl) or $300 \mathrm{~g} / \mathrm{d}$ of Gln for $21 \mathrm{~d}$ starting within $48 \mathrm{~h}$ of calving; $d 1$ is prior to the initiation of treatments.

to $0.68 \pm 0.169 \mathrm{~m} M$ at calving and $1.18 \pm 0.151 \mathrm{~m} M$ during the treatment period.

\section{Immunological Parameters}

Total leukocyte and differential counts are shown in Table 4. Because there was no treatment effect, data were pooled and are presented by day of sampling only.

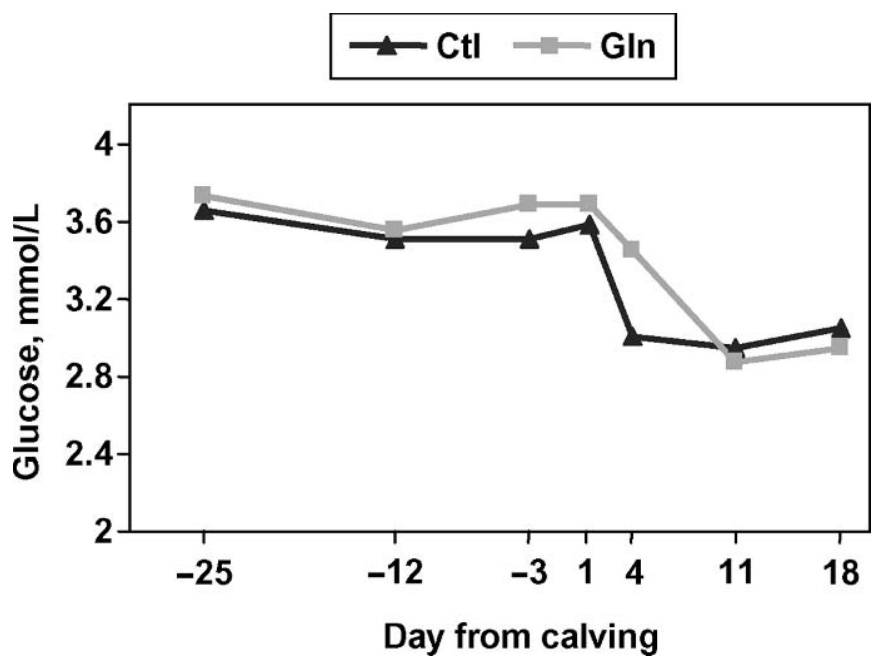

Figure 4. Plasma glucose concentrations (pooled SEM $=0.177$ ) There was a tendency for a treatment $\times$ linear effect $(P=0.10)$. Cows were abomasally infused with water (control, Ctl) or $300 \mathrm{~g} / \mathrm{d}$ of Gln for $21 \mathrm{~d}$ starting within $48 \mathrm{~h}$ of calving; $\mathrm{d} 1$ is prior to the initiation of treatments.

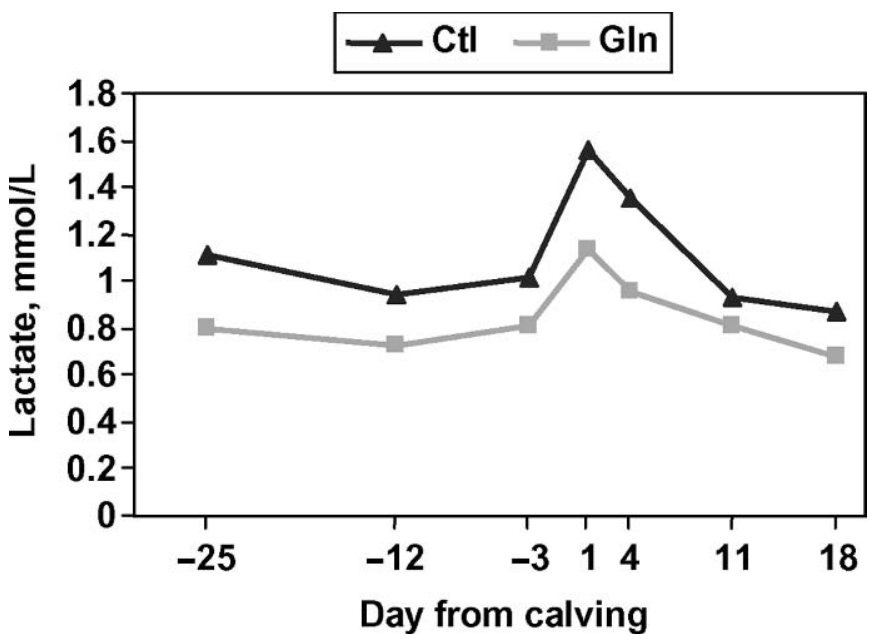

Figure 5. Blood lactate concentrations (pooled $\mathrm{SEM}=0.227$ ). There was no treatment effect [trt $\times$ (pre vs. post), $P=0.98$ ]. Concentrations were lower precalving than on the day of calving (pre vs. $d$ $1 ; P=0.007)$. There was a linear effect during the treatment period $(P=0.05)$. Cows were abomasally infused with water (control, $\mathrm{Ctl})$ or $300 \mathrm{~g} / \mathrm{d}$ of Gln for $21 \mathrm{~d}$ starting within $48 \mathrm{~h}$ of calving; $\mathrm{d} 1$ is prior to the initiation of treatments.

The total leukocyte count was significantly increased on $\mathrm{d} 1$ compared with the precalving period (pre vs. $\mathrm{d}$ $1, P=0.001$ ), and then remained constant from $\mathrm{d} 4$ to 18. Relative to the precalving period, the proportions of eosinophils and lymphocytes decreased on $\mathrm{d} 1$, whereas that of neutrophils increased $(P<0.005)$. As a result of

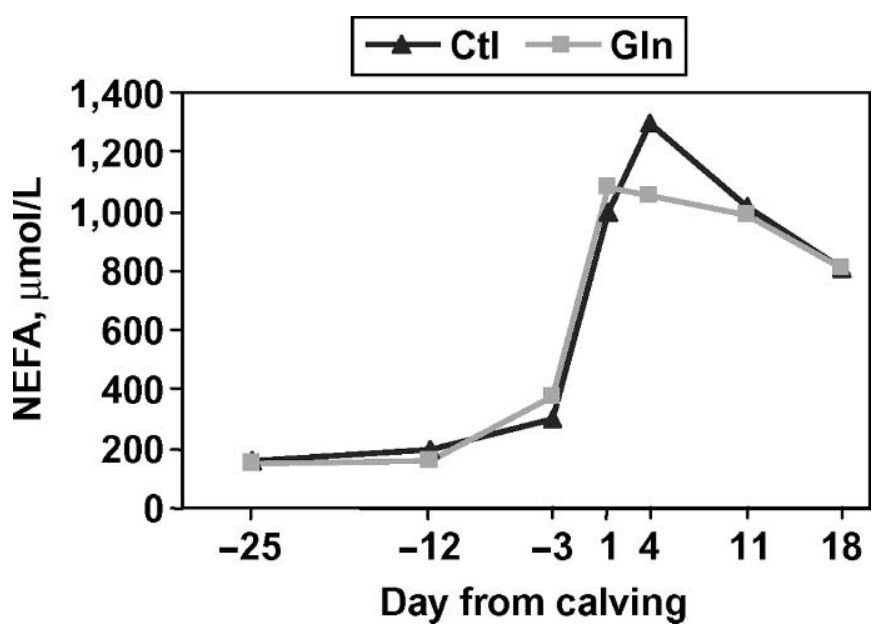

Figure 6. Plasma NEFA concentrations (pooled SEM = 152.6). There was no treatment effect [trt $\times$ (pre vs. post), $P=0.65$ ]. Concentrations were lower precalving than on the day of calving (pre vs. post d $1, P<0.001$ ), and during the treatment period (pre vs. post, $P<0.001$ ). There was a linear effect during the treatment period $(P=0.05)$. Cows were abomasally infused with water (control, Ctl) or $300 \mathrm{~g} / \mathrm{d}$ of Gln for $21 \mathrm{~d}$ starting within $48 \mathrm{~h}$ of calving; $\mathrm{d} 1$ is prior to the initiation of treatments. 


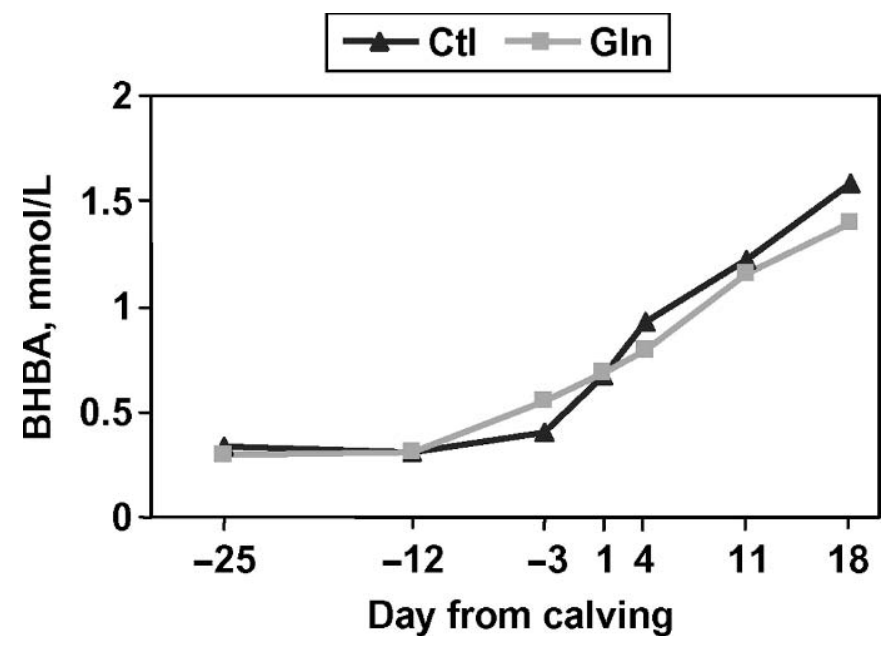

Figure 7. Blood BHBA concentrations (pooled $\mathrm{SEM}=0.244$ ). There was no treatment effect [trt $\times$ (pre vs. post), $P=0.63$ ], but there was a linear effect during the treatment period $(P<0.001)$. Cows were abomasally infused with water (control, Ctl) or $300 \mathrm{~g} / \mathrm{d}$ of Gln for $21 \mathrm{~d}$ starting within $48 \mathrm{~h}$ of calving; $\mathrm{d} 1$ is prior to the initiation of treatments.

the increase in total leukocyte numbers, this resulted in no change in total numbers of lymphocytes but an increase in the number of neutrophils (linear effect, $P$ $<0.001)$.

The proliferative response of lymphocytes, incubated either in AS or FBS, was not different between treatments (Table 5). With the exception of cells incubated at the highest ConA level, proliferation was not different between $\mathrm{d}-25$ and the treatment period (pre vs. post: $P>0.05$ ). For cells incubated with FBS, there was a linear increase in proliferation at the lower ConA levels $(P<0.10)$ as lactation progressed, but this effect was not observed when cells were incubated with AS.

Table 6 shows the relative abundance of the T lymphocyte subpopulations. Because $\mathrm{T}$ cells may carry more than one receptor type, the total cell numbers for a particular day and treatment were $>100 \%$. Treatment had no effect on the relative abundance of $\mathrm{CD}^{+} \mathrm{T}$ cells (17.1\% across treatments). For $\mathrm{CD} 4^{+}$cells, there was a trt $\times$ linear interaction $(P=0.05)$, primarily because of differences between the treatments on $d 4$. These changes were also reflected in the temporal increase in the $\mathrm{CD}^{+}: \mathrm{CD}^{+}$ratio (trt $\times$linear effect, $P=0.04$ ). In comparison with $d-25$ values, the percentage of $T$ cells carrying the CD2 receptor was higher for the Glntreated cows than the control cows [trt $\times$ (pre vs. post), $P=0.04$; Table 6]. The relative amounts of B lymphocytes tended to vary over time between the 2 treatments (trt $\times$ time quadratic, $P=0.09$ ). For the control cows, the proportion of $B$ cells was greater on $d 11$ vs. $d 4$ or 18 , but this difference was not observed in the Glntreated cows. The relative amount of monocytes (as a proportion of PBMC) was increased by the Gln infusion [trt $\times$ (pre vs. post), $P=0.003$ ]. For control, the cows averaged 30.9 and $30.2 \%$ for the precalving and treatment periods, respectively, whereas for the Gln treatment, the cows averaged 25.3 and $37.2 \%$ for the 2 time periods. Lymphocyte populations did not change over the course of the treatment period (linear and quadratic, $P>0.05$ ), but the percentage of monocytes decreased as lactation progressed (Table 6).

Treatment had no effect on IFN- $\gamma$ concentrations (Table 7); however, there was an effect of physiological stage (pre vs. post, $P<0.05$ ). Concentrations were higher precalving $(1139.5 \mathrm{pg} / \mathrm{mL})$ than postcalving (851.3 pg/mL) for PBMC incubated in FBS; however, for cells incubated in AS, this effect was not evident.

Lymphocyte Gln concentrations tended to increase with Gln infusion [trt $\times$ (pre vs. post), $P=0.07$; Table 8]. This was due to a $20 \%$ decline in control cows, whereas Gln supplementation maintained postpartum concentrations similar to precalving. Unlike Gln, Glu concentrations were unaffected by treatment $(P=0.93)$ and averaged $15.17 \mathrm{nmol} / 10^{7}$ cells. Lymphocyte His concentrations tended to increase $(P=0.07)$ from the pre-

Table 4. Total leukocyte and differential blood count ${ }^{1}$

\begin{tabular}{|c|c|c|c|c|c|c|c|c|c|c|c|c|c|}
\hline \multirow[b]{3}{*}{ Count } & \multirow{2}{*}{\multicolumn{7}{|c|}{ Day relative to calving $^{2}$}} & \multirow[b]{3}{*}{ SEM } & \multirow{3}{*}{$\begin{array}{l}P \\
\text { Trt } \times \\
\text { (pre vs. } \\
\text { post) }\end{array}$} & \multicolumn{4}{|c|}{ Time $P$} \\
\hline & & & & & & & & & & \multirow{2}{*}{$\begin{array}{l}\text { Pre vs. } \\
\text { post }\end{array}$} & \multirow{2}{*}{$\begin{array}{l}\text { Pre vs. } \\
\text { d } 1\end{array}$} & \multirow{2}{*}{$\begin{array}{l}\text { Post } \\
\text { lin }\end{array}$} & \multirow{2}{*}{$\begin{array}{l}\text { Post } \\
\text { quad }\end{array}$} \\
\hline & -25 & -12 & -3 & 1 & 4 & 11 & 18 & & & & & & \\
\hline Basophils & 0.4 & 0.5 & 0.7 & 0.3 & 0.6 & 0.6 & 0.8 & 0.24 & 0.55 & 0.55 & 0.38 & 0.58 & 0.66 \\
\hline Eosinophils & 11.3 & 8.0 & 6.5 & 3.9 & 4.8 & 4.0 & 5.7 & 1.42 & 0.96 & 0.001 & 0.001 & 0.59 & 0.37 \\
\hline Lymphocytes & 43.3 & 39.3 & 33.4 & 27.9 & 36.5 & 42.9 & 37.3 & 3.27 & 0.24 & 0.93 & 0.003 & 0.85 & 0.10 \\
\hline
\end{tabular}

${ }^{1}$ LSM are presented with the pooled SEM. Trt = treatment; pre = precalving; post = postcalving; lin = linear effect; quad = quadratic effect.

${ }^{2}$ Days $-25,-12$, and -3 values are precalving; $\mathrm{d} 4,11$, and 18 are postcalving values used for contrast. 
Table 5. Lymphocyte proliferative response (optical density units) of peripheral blood mononuclear cells to concanavalin A (ConA) ${ }^{1}$

\begin{tabular}{|c|c|c|c|c|c|c|c|c|c|c|c|c|}
\hline \multirow[b]{3}{*}{ Response } & \multirow[b]{3}{*}{ Trt } & & & & & & \multicolumn{3}{|c|}{ Trt $\times$ time $P$} & \multicolumn{3}{|c|}{ Time $P$} \\
\hline & & \multicolumn{4}{|c|}{ Day $^{2}$} & \multirow[b]{2}{*}{ SEM } & \multirow{2}{*}{$\begin{array}{l}\text { Trt } \times \\
\text { (pre vs. } \\
\text { post) }\end{array}$} & \multirow{2}{*}{$\begin{array}{l}\text { Trt } \times \\
\text { lin } \\
\text { post }\end{array}$} & \multirow{2}{*}{$\begin{array}{l}\text { Trt } \times \\
\text { quad } \\
\text { post }\end{array}$} & \multirow{2}{*}{$\begin{array}{l}\text { Pre } \\
\text { vs. } \\
\text { post }\end{array}$} & \multirow{2}{*}{$\begin{array}{l}\text { Post } \\
\text { lin }\end{array}$} & \multirow{2}{*}{$\begin{array}{l}\text { Post } \\
\text { quad }\end{array}$} \\
\hline & & -25 & 4 & 11 & 18 & & & & & & & \\
\hline \multicolumn{13}{|l|}{ FBS } \\
\hline \multicolumn{13}{|l|}{ ConA $^{3}$} \\
\hline \multirow{2}{*}{0.06} & Control & 0.32 & 0.27 & 0.27 & 0.50 & 0.120 & 0.84 & 0.82 & 0.13 & 0.62 & 0.03 & 0.73 \\
\hline & Gln & 0.21 & 0.08 & 0.41 & 0.36 & & & & & & & \\
\hline \multirow[t]{2}{*}{0.125} & Control & 0.57 & 0.66 & 0.54 & 0.79 & 0.135 & 0.65 & 0.35 & 0.31 & 0.21 & 0.07 & 0.66 \\
\hline & Gln & 0.47 & 0.44 & 0.72 & 0.85 & & & & & & & \\
\hline \multirow[t]{2}{*}{0.50} & Control & 0.79 & 1.39 & 1.03 & 1.02 & 0.146 & 0.63 & 0.20 & 0.83 & 0.03 & 0.33 & 0.30 \\
\hline & Gln & 0.72 & 0.97 & 0.88 & 1.02 & & & & & & & \\
\hline \multicolumn{13}{|l|}{$\begin{array}{l}\text { AS } \\
\text { ConA }^{3}\end{array}$} \\
\hline \multirow[t]{2}{*}{0.125} & Control & 0.12 & 0.08 & 0.08 & 0.10 & 0.059 & 0.38 & 0.66 & 0.29 & 0.92 & 0.36 & 0.42 \\
\hline & Gln & 0.06 & 0.04 & 0.14 & 0.10 & & & & & & & \\
\hline \multirow[t]{2}{*}{0.50} & Control & 0.83 & 0.91 & 0.59 & 0.83 & 0.148 & 0.12 & 0.39 & 0.26 & 0.24 & 0.72 & 0.31 \\
\hline & Gln & 0.42 & 0.66 & 0.77 & 0.84 & & & & & & & \\
\hline \multirow[t]{2}{*}{1.00} & Control & 0.93 & 1.31 & 1.22 & 1.13 & 0.160 & 0.92 & 0.74 & 0.28 & 0.04 & 0.46 & 0.28 \\
\hline & Gln & 0.72 & 1.12 & 0.77 & 1.05 & & & & & & & \\
\hline
\end{tabular}

\footnotetext{
${ }^{1} \mathrm{LSM}$ are presented with the pooled SEM. Trt = treatment; pre = precalving; post = postcalving; lin = linear effect; quad = quadratic effect; FBS = fetal bovine serum; AS = autologous serum

${ }^{2}$ Day -25 is precalving; $\mathrm{d} 4,11$, and 18 are postcalving values used for the contrasts.

${ }^{3} \mathrm{ConA}$ concentrations are micrograms per milliliter.
}

calving $\left(0.34 \mathrm{nmol} / 10^{7}\right.$ cells $)$ to the postcalving $(0.44$ $\mathrm{nmol} / 10^{7}$ cells) period for the control cows, but remained constant for the Gln-treated cows $(0.49$ and $0.45 \mathrm{nmol} /$ $10^{7}$ cells for the precalving and treatment periods, respectively; Table 8). Glutamine supplementation resulted in a decrease in both Thr and Val concentrations $(P=0.03)$. Valine concentrations for the control cows were 3.40 and $3.79 \mathrm{nmol} / 10^{7}$ cells during the precalving and treatment periods, respectively, whereas for the Gln cows, concentrations were 6.60 and $5.02 \mathrm{nmol} / 10^{7}$ cells for the same time periods. Essential AA concentrations did not differ between the precalving period and d 1, with the exception of Thr and Val, which tended to decrease at calving. For the NEAA, Ala tended to decrease at calving, Asn and Asp decreased at calving, and Gln increased at calving.

Table 6. Characterization of peripheral blood mononuclear cell subpopulations $(\%)^{1}$

\begin{tabular}{|c|c|c|c|c|c|c|c|c|c|c|c|c|}
\hline \multirow[b]{3}{*}{ Subpopulation } & \multirow[b]{3}{*}{ Trt } & & & & & & \multicolumn{3}{|c|}{ Trt $\times$ time $P$} & \multicolumn{3}{|c|}{ Time $P$} \\
\hline & & \multicolumn{4}{|c|}{ Day } & \multirow[b]{2}{*}{ SEM } & \multirow{2}{*}{$\begin{array}{l}\text { Trt } \times \\
\text { (pre vs. } \\
\text { post) }\end{array}$} & \multirow{2}{*}{$\begin{array}{l}\text { Trt } \times \\
\text { lin } \\
\text { post }\end{array}$} & \multirow{2}{*}{$\begin{array}{l}\text { Trt } \times \\
\text { quad } \\
\text { post } \\
\end{array}$} & \multirow{2}{*}{$\begin{array}{l}\text { Pre } \\
\text { vs. } \\
\text { post }\end{array}$} & \multirow{2}{*}{$\begin{array}{l}\text { Post } \\
\text { lin }\end{array}$} & \multirow{2}{*}{$\begin{array}{l}\text { Post } \\
\text { quad }\end{array}$} \\
\hline & & -25 & 4 & 11 & 18 & & & & & & & \\
\hline \multicolumn{13}{|l|}{ T lymphocytes } \\
\hline \multirow[t]{2}{*}{ CD2 } & Control & 64.1 & 57.5 & 69.2 & 68.7 & 4.53 & 0.04 & 0.20 & 0.15 & 0.02 & 0.13 & 0.36 \\
\hline & Gln & 48.4 & 63.5 & 62.7 & 64.5 & & & & & & & \\
\hline \multirow{2}{*}{ CD4 } & Control & 30.6 & 29.9 & 36.4 & 37.5 & 3.45 & 0.11 & 0.05 & 0.41 & 0.001 & 0.42 & 0.40 \\
\hline & Gln & 24.0 & 37.3 & 35.7 & 34.1 & & & & & & & \\
\hline \multirow[t]{2}{*}{ CD8 } & Control & 16.9 & 16.2 & 18.7 & 19.5 & 2.55 & 0.71 & 0.75 & 0.28 & 0.24 & 0.12 & 0.83 \\
\hline & Gln & 13.8 & 15.5 & 15.3 & 17.7 & & & & & & & \\
\hline \multirow[t]{2}{*}{$\gamma-\delta$} & Control & 11.8 & 12.8 & 14.7 & 12.0 & 1.81 & 0.27 & 0.92 & 0.02 & 0.91 & 0.47 & 0.55 \\
\hline & Gln & 9.8 & 9.6 & 7.7 & 8.6 & & & & & & & \\
\hline \multirow[t]{2}{*}{$\mathrm{CD} 4: \mathrm{CD} 8^{2}$} & Control & 2.2 & 2.2 & 2.3 & 2.5 & 0.38 & 0.33 & 0.04 & 0.93 & 0.13 & 0.24 & 0.57 \\
\hline & Gln & 1.9 & 3.0 & 2.4 & 2.1 & & & & & & & \\
\hline \multirow[t]{2}{*}{ B lymphocytes } & Control & 13.4 & 15.7 & 18.9 & 12.3 & 3.07 & 0.37 & 0.42 & 0.09 & 0.95 & 0.69 & 0.34 \\
\hline & Gln & 16.4 & 14.4 & 13.6 & 15.5 & & & & & & & \\
\hline \multirow[t]{2}{*}{ Monocytes } & Control & 30.9 & 39.2 & 26.0 & 25.5 & 2.48 & 0.01 & 0.73 & 0.84 & 0.01 & 0.01 & 0.01 \\
\hline & Gln & 25.3 & 45.1 & 33.4 & 33.0 & & & & & & & \\
\hline
\end{tabular}

${ }^{1}$ LSM are presented with the pooled SEM. Trt = treatment; pre = precalving; post = postcalving; lin = linear effect; quad = quadratic effect.

${ }^{2}$ Data are presented as ratios, not as percentages. 
Table 7. Interferon- $\gamma$ concentrations in supernatants of concanavalin A-stimulated peripheral blood mononuclear cells (pg/mL) ${ }^{1}$

\begin{tabular}{|c|c|c|c|c|c|c|c|c|c|c|c|c|c|c|c|}
\hline \multirow[b]{3}{*}{ Supernatant } & \multicolumn{8}{|c|}{ Day relative to calving } & \multicolumn{4}{|c|}{ Trt $\times$ time $P$} & \multicolumn{3}{|c|}{ Time $P$} \\
\hline & \multicolumn{4}{|c|}{ Control } & \multicolumn{4}{|c|}{ Gln } & \multirow[b]{2}{*}{$\mathrm{SEM}^{2}$} & \multirow{2}{*}{$\begin{array}{l}\text { Trt } \times \\
\text { (pre vs. } \\
\text { post) }\end{array}$} & \multirow{2}{*}{$\begin{array}{l}\text { Trt } x \\
\text { lin } \\
\text { post }\end{array}$} & \multirow{2}{*}{$\begin{array}{l}\text { Trt } \times \\
\text { quad } \\
\text { post }\end{array}$} & \multirow{2}{*}{$\begin{array}{l}\text { Pre } \\
\text { vs. } \\
\text { post }\end{array}$} & \multirow{2}{*}{$\begin{array}{l}\text { Post } \\
\text { lin }\end{array}$} & \multirow{2}{*}{$\begin{array}{l}\text { Post } \\
\text { quad }\end{array}$} \\
\hline & -25 & 4 & 11 & 18 & -25 & 4 & 11 & 18 & & & & & & & \\
\hline FBS & 1,124 & 801 & 841 & 706 & 1,156 & 934 & 837 & 1,025 & - & 0.61 & 0.51 & 0.19 & 0.05 & 0.92 & 0.83 \\
\hline AS & 1,046 & 909 & 785 & 581 & 1,317 & 1,262 & 1,146 & 919 & 275.3 & 0.85 & 0.98 & 0.97 & 0.25 & 0.20 & 0.81 \\
\hline
\end{tabular}

${ }^{1}$ LSM are presented with the pooled SEM. Trt = treatment; pre = precalving; post = postcalving; lin = linear effect; quad = quadratic effect; FBS = fetal bovine serum, AS = autologous serum.

${ }^{2}$ SEM not available for FBS data because the data were log transformed.

\section{DISCUSSION}

\section{Milk Yield and DMI}

The numerical increase in milk yield $(1.9 \mathrm{~kg})$ with Gln supplementation was higher than the significant response $(1.3 \mathrm{~kg})$ observed in 6 cows also infused with $300 \mathrm{~g} / \mathrm{d}$ of Gln at 6 wk postpartum (Meijer et al., 1995b, Experiment 1), but the interanimal variation in the current study precluded statistical significance. Unlike the experiment by Meijer et al. (1995b, Experiment 1), Plaizier et al. (2001) also did not observe any response in milk yield in cows averaging 63 DIM at the initiation of a study in which they received a postruminal infusion of Gln of up to $300 \mathrm{~g} / \mathrm{d}$ for $4 \mathrm{~d}$. No milk response was also reported by Meijer et al. (1995b, Experiment 2), but in the latter study, Gln decreased DMI. Milk protein content and yield were not significantly affected by an increased duodenal supply of Gln, as previously observed by Plaizier et al. (2001) and Meijer et al. (1995b).

Dry matter intake was not influenced by Gln supplementation. This observation is similar to that previously reported, even though the stage of lactation and the length of infusion varied between studies. In the study by Plaizier et al. (2001), DMI was not different among cows (63 DIM) receiving incremental amounts (from 0 to $300 \mathrm{~g} / \mathrm{d}$ ) of Gln postruminally for $4 \mathrm{~d}$. Meijer et al. (1995b) reported no difference in DMI between cows receiving 0 or $300 \mathrm{~g} / \mathrm{d}$ of Gln abomasally in one study, but did observe a decrease in intake with Gln supplementation in a subsequent study using the same cows and with the same level of supplementation. The decline in intake during the last $7 \mathrm{~d}$ precalving is consistent with previously published results (Doepel et al., 2002 ) and may be associated with animal factors (physical fill, endocrine changes) and dietary factors, as discussed by Grummer et al. (2004).

\section{Metabolic Parameters}

Glutamine infusion resulted in plasma Gln concentrations $108 \mu M$ higher than those in control cows, showing quite clearly that the abomasal infusion was successful in delivering Gln to the duodenum and that at least part of it escaped catabolism across the intestine and was absorbed into the bloodstream.

The lower concentration of total EAA in the Glntreated cows may be the result of different metabolic effects of Gln. There is evidence that Gln stimulates protein synthesis (Reecy et al., 1996) or decreases protein degradation (Vom Dahl and Häusinger, 1996). Improvements in net anabolism (greater milk protein output) would lower concentrations of EAA. However, Plaizier et al. (2001) also observed a trend of decreased plasma concentrations of EAA with Gln treatment in cows at a later stage of lactation without any effect on milk protein yield. In that study, as in the current study, increased urea concentrations indicated increased ureagenesis, which has been suggested to elevate hepatic removal of EAA (Lobley et al., 1995).

As DIM progressed, the Gln concentration decreased linearly, indicating an increasing demand with advancing lactation. Previous studies have also demonstrated that Gln concentrations postcalving remain below precalving concentrations for up to 6 wk postpartum (Meijer et al., 1995a; Doepel et al., 2002).

The decrease in plasma AA concentrations on $\mathrm{d} 1$ relative to precalving likely reflects the substantial reduction in DMI at calving and an increase in protein synthesis for growth of the mammary gland. However, by d 18, plasma concentrations of EAA in the control cows (with the exception of His) increased and returned to, or were even higher than, precalving values. This result suggests that relative to the other EAA, His may have been limiting. Unlike the EAA, the concentrations of most of the NEAA were lower on d 18 than during the precalving period. This contrasts with the results of Doepel et al. (2002) in which NEAA concentrations, with the exception of Gln at $21 \mathrm{~d}$ postcalving, were equivalent to precalving levels. In that study, dietary protein was higher and milk yield lower than in the current study.

The tendency for the increase in plasma urea $\mathrm{N}$ concentrations with the Gln treatment is probably the result of Gln deamination in the gut and liver. The excess 
Table 8. Lymphocyte AA concentrations $\left(\mathrm{nmol} / 10^{7} \text { cells }\right)^{1}$

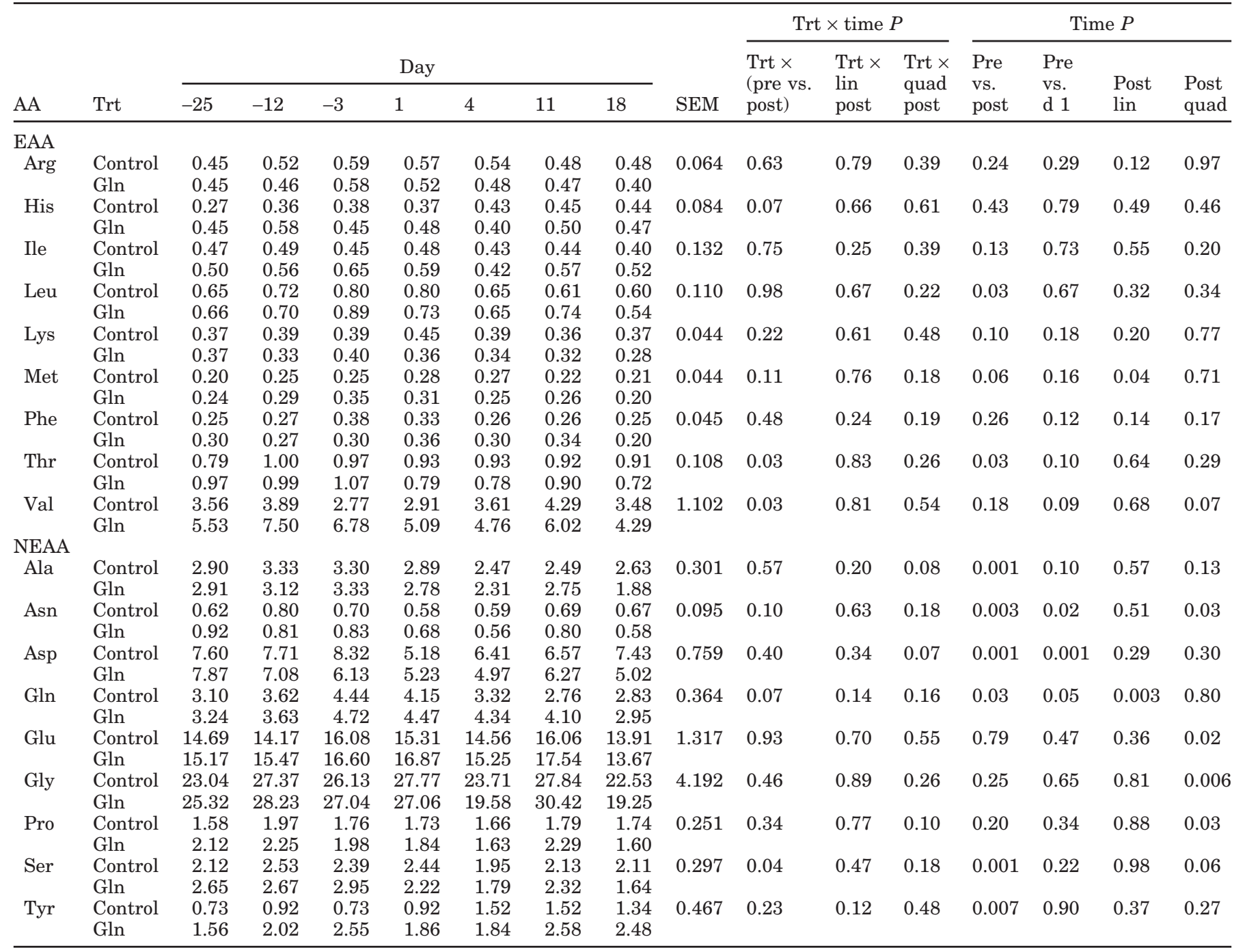

${ }^{1}$ LSM are presented with the pooled SEM. Trt = treatment; pre = precalving; post = postcalving; lin = linear effect; quad = quadratic effect; $\mathrm{EAA}=$ essential AA; NEAA = nonessential AA.

${ }^{2}$ Days $-25,-12$, and -3 are precalving; $\mathrm{d} 4,11$, and 18 are postcalving.

$\mathrm{N}$ will eventually contribute to hepatic ureagenesis, and therefore to the increase in circulating urea $\mathrm{N}$ concentrations. Plaizier et al. (2001) also reported that postruminal Gln infusion resulted in a modest numerical increase in urea concentration.

Plasma glucose concentrations averaged over the treatment period were unaffected by the Gln infusion. This does not preclude the conversion of Gln to glucose, or the sparing of glucose at the intestinal level. Homeostatic controls maintain circulating glucose concentrations within a narrow range; thus, increases in gluconeogenic activity are not reflected in plasma concentrations. For example, in human subjects (Perriello et al., 1997) following a Gln infusion of $11.4 \mu \mathrm{mol} / \mathrm{kg}$ per min, postabsorptive plasma glucose concentrations re- mained unchanged relative to pretreatment levels, but the conversion of Gln to glucose increased from 0.66 to $4.48 \mu \mathrm{mol} / \mathrm{kg}$ per min. In the present study, the maximum supply of glucose precursor offered by the supplemental Gln $(41 \mathrm{mmol} / \mathrm{h})$ represents up to $10 \%$ of glucose production in early lactation. The decrease in glucose concentrations after calving is typical of this period (Doepel et al., 2002; Reynolds et al., 2003) and is indicative of the high glucose demands imposed by milk synthesis.

Lactate concentrations were not different in the preand postcalving periods. This is in contrast to the values reported by Reynolds et al. (2003), in which lactate concentrations were lower postcalving than precalving. This may be related to the manner in which the data 
were analyzed. Reynolds et al. (2003) compared each sampling day postcalving with d 19 precalving, whereas in the present study, the average across all sampling days within a period was compared. When the data from d 19 are compared with d -25 , then one can see a relative change in concentration similar to that reported by Reynolds et al. (2003).

The gradual rise in plasma NEFA concentrations precalving followed by the rapid increase at calving has been observed in many studies (see the review by Drackley, 1999). The spike at calving suggests that NEFA concentrations are regulated by feed intake and hormonal status. Similar to NEFA concentrations, BHBA concentrations were lower in the precalving than the postcalving period. This is indicative of body fat mobilization and the limited capacity of the liver for oxidation. The steady rise in BHBA concentrations after calving is similar to that reported by Veenhuizen et al. (1991) for cows that received a ketosis induction protocol, and indicates that the cows were in negative energy balance. Averaged across treatments, cows were in greater negative net energy balance on d $21(-7.9$ $\mathrm{Mcal} / \mathrm{kg})$ than on $\mathrm{d} 4(-4.8 \mathrm{Mcal} / \mathrm{kg})$.

\section{Immunological Parameters}

Total leukocyte count increased on the day of calving primarily because of an increase in neutrophils, in line with previous reports (Preisler et al., 2000). Unlike the total leukocyte count, lymphocyte proliferation was consistent over the periparturient period. This contrasts with the results of Kehrli et al. (1989), who reported that the proliferative response induced by ConA in Holstein heifers was depressed during the first week postpartum relative to the response 2 wk prepartum, and that the reduction in proliferative response induced by phytohemagglutinin $\mathrm{P}$ began at 2 wk prepartum. The differences observed between the 2 studies may be related to the frequency and time of sampling and to culture conditions. In the study by Kehrli et al., blood samples were obtained weekly from 5 to $3 \mathrm{wk}$ precalving and 3 times weekly for the 2 wk surrounding calving, whereas in the present study, samples were obtained only once precalving $(\mathrm{d}-25)$ and once weekly postcalving. It is possible that a depression in proliferative response would have been observed had the sampling frequency precalving been increased. Although there was no overall time effect, at low ConA concentrations, cells incubated with FBS showed a linear increase in their proliferative response after calving. These results suggest that lymphocyte proliferation in these particular culture conditions is impaired shortly after calving relative to $3 \mathrm{wk}$ postcalving. This parturition effect is supported by previously reported studies showing that as lactation progresses, lymphocyte response to mitogens increases (Van Kampen and Mallard, 1997). However, this same response was not observed when the cells were incubated with AS, suggesting that factors in cow serum may influence the lymphocyte response to ConA. As reported in Mallard et al. (1998), blood factors such as cortisol, growth hormone, and IGF-I contribute to the variation in the blastogenesis response in periparturient cows. The lack of lymphocyte proliferation response to Gln suggests that the Gln supply from intestinal absorption and endogenous synthesis was adequate to meet the needs of the immune cells, and that a more catabolic state is required to induce a Gln deficiency.

On average, over the periparturient period the population of T lymphocytes carrying the CD4 receptor was similar to that previously reported (Van Kampen and Mallard, 1997; Kimura et al., 1999). Kimura and colleagues reported a reduction precalving followed by an increase postcalving, but this did not occur in the current study. The various results are difficult to compare because the sampling schedules were different between studies and short-term responses may have occurred within the critical time leading to calving. The difference between the control and Gln-treated cows in the abundance of $\mathrm{CD} 4^{+}$cells during the treatment period was primarily due to the difference on $d 4$. For the control cows, the percentage of $\mathrm{CD} 4^{+}$cells was the same on $d-25$ and 4 , whereas for the Gln-treated cows, there was an increase of more than $50 \%$ from $d-25$ to 4 . The $\mathrm{CD} 4^{+}$cells play a role in both the humoral and cellmediated immune systems, so the increase at $d 4$ with the Gln treatment would indicate, at least in the short term, an improvement in immunocompetence. The relevance of this observation to the overall health of the postpartum cow may be limited because the populations of $\mathrm{CD}^{+}$cells in the 2 treatments were similar on $\mathrm{d} 11$ and 18.

The ratio of $\mathrm{CD}^{+}: \mathrm{CD}^{+}$was higher on $\mathrm{d} 4$ for the Gln-treated cows than for the control cows. In humans, a ratio of 2 or higher is indicative of immunocompetence (Harp et al., 1991), so the elevated ratio on $d 4$ in the Gln cows may be an indication of a short-term improvement in immune status. Nonetheless, ratios exceeded 2 for all cows postcalving and, based on the human data, this might indicate these animals were in a sound immunocompetent state. Thus, responses to additional Gln might be marginal. For other animals, under less favorable conditions, such improvements in ratio may be more beneficial.

To the authors' knowledge, this is the first study to report the effects of Gln on monocyte abundance. The monocyte population was significantly increased as a result of the Gln treatment. Monocytes, which play an 
important role in controlling infection in the postparturient period, are known to require Gln for cytokine production. It appears that Gln may also be required for monocyte proliferation, and that it is the dual action of Gln on cell numbers and cytokine production that contributes to the protective effects of monocytes.

Glutamine supplementation had no effect on the production of IFN- $\gamma$, in contrast with findings in humans (Rohde et al., 1996). This may be due to differences in incubation conditions, in which $300 \mu M$ of Gln was added to the medium for the human studies but none was supplemented in the current work. Even though plasma concentrations in the present study were roughly equal to that in the media, this does not ensure that the same response would be generated, as a variety of hormonal and metabolic factors would likely be influencing the response in the animal. Of course, there may also be an innate difference between human and ruminant lymphocytes in terms of IFN- $\gamma$. Certainly, glucose and Gln metabolism by lymphocytes differs between ruminants and rats (Wu and Greene, 1992). Rat lymphocytes preferentially used Gln as their major energy substrate, whereas the bovine lymphocytes preferred glucose.

Blood lymphocyte Gln concentrations were similar to those reported by McNeil (2001) in sheep and tended to be higher in the Gln-treated cows than in the control cows. This is probably due to the elevation in plasma Gln concentrations in the Gln-infused cows. Based on a $K_{\mathrm{m}}$ of $142 \mu M$ (as in human lymphocytes; Schröder et al., 1990), the $35 \%$ elevation in plasma Gln concentrations would increase the rate of transport of Gln into lymphocytes by $16 \%$. Nonetheless, the Gln concentrations are relatively low, only $25 \%$ those of Glu, again in line with findings in sheep lymphocytes (Lobley et al., 2001). This is despite the fact that the rate of Glu transport into cells is 10-fold lower than that of Gln (McDermott and Butler, 1993) and suggests that Glu is synthesized in the cells using Gln as the precursor. This was confirmed by studies in vitro showing that rapid Gln entry is accompanied by release of ammonia from the amide $\mathrm{N}$ and export of Glu. In addition, studies in sheep in vivo demonstrated that $65 \%$ of lymphocyte Glu was derived from plasma Gln. The rates of influx and efflux of metabolites (including Gln, Glu, and Ser) through $\mathrm{Na}^{+}$-dependent transporters determine cell volume, and this regulates cellular activities (Häusinger et al., 1994). Thus, increased movements of Gln may alter lymphocyte metabolism even if intracellular concentrations are unaltered or are changed only minimally.

\section{CONCLUSIONS}

Glutamine supplemented postruminally had limited effects on metabolism, immune status, and cow produc- tivity over the first 3 wk postcalving. Numerical increases in milk and milk protein yield may suggest the relief of a certain limitation on cow productivity with infusion of Gln. Immunocompetence, as measured by lymphocyte proliferation, IFN- $\gamma$ concentrations, and changes in T-cell subpopulations, was not enhanced by the additional duodenal Gln supply over the 3-wk treatment period.

\section{ACKNOWLEDGMENTS}

The authors gratefully thank the staff of the Lennoxville Dairy and Swine Research Centre for animal care; V. Dostie, M. Dupuis, M. Léonard, and B. Vallerand for their dedicated technical support; and S. Méthot for statistical analyses. The authors also wish to acknowledge the financial support of Dairy Farmers of Canada, the Natural Sciences and Engineering Research Council of Canada, and Agriculture and Agri-Food Canada (Lennoxville Research Contribution no. 892) as well as Ajinomoto (Tokyo, Japan) for supplying the Gln.

\section{REFERENCES}

AOAC. 1996. Official Methods of Analysis. 16th ed. Association of Official Analytical Chemists, Arlington, VA.

Benson, J. A., C. K. Reynolds, P. C. Aikman, B. Lupoli, and B. E. Beever. 2002. Effects of abomasal long chain fatty acid infusion on splanchnic nutrient metabolism in lactating dairy cows. J. Dairy Sci. 85:1804-1814.

Brunton, J. A., R. F. P. Betolo, P. B. Pencharz, and R. O. Ball. 1999. Proline ameliorates arginine deficiency during enteral but not parental feeding in neonatal piglets. Am. J. Physiol. 272:E223E237.

Calder, A. G., K. E. Garden, S. E. Anderson, and G. E. Lobley. 1999. Quantitation of blood and plasma amino acids using isotope dilution electron impact gas chromatography/mass spectrometry with $\mathrm{U}^{13} \mathrm{C}$ amino acids as internal standards. Rapid Commun. Mass Spectrom. 13:2080-2083.

Canadian Council on Animal Care (CCAC). 1993. Guide to the Care and Use of Experimental Animals. Vol. 1, 2nd ed. E. D. Olfert, B. M. Cross, and A. A. McWilliam, ed. CCAC, Ottawa, Ontario, Canada.

Chang, W., K. D. Yang, and M. Shaio. 1999. Effect of glutamine on Th1 and Th2 cytokine responses of human peripheral blood mononuclear cells. Clin. Immunol. 93:294-301.

Doepel, L., H. Lapierre, and J. J. Kennelly. 2002. Peripartum performance and metabolism of dairy cows in response to prepartum energy and protein intake. J. Dairy Sci. 85:2315-2334.

Drackley, J. K. 1999. Biology of dairy cows during the transition period: The final frontier? J. Dairy Sci. 82:2259-2273.

Eigel, W. N., J. E. Butler, C. A. Ernstrom, H. M. Farrell, Jr., V. R. Harwalkar, R. Jenness, and R. Whitney. 1984. Nomenclature of proteins of cow's milk: Fifth revision. J. Dairy Sci. 67:1599-1631.

Fukuda, K., Y. Hirai, H. Yoshida, T. Nakajima, and T. Usui. 1982. Free amino acid content of lymphocytes and granulocytes compared. Clin. Chem. 28:1758-1761.

Gate, J. J., D. S. Parker, and G. E. Lobley. 1999. The metabolic fate of the amido-N group of glutamine in the tissues of the gastrointestinal tract in $24 \mathrm{~h}$-fasted sheep. Br. J. Nutr. 81:297-306.

Goff, J. P., and R. L. Horst. 1997. Physiological changes at parturition and their relationship to metabolic disorders. J. Dairy Sci. 80:1260-1268. 
Grummer, R. R., D. G. Mashek, and A. Hayirli. 2004. Dry matter intake and energy balance in the transition period. Vet. Clin. North Am. Food Anim. Pract. 20:447-470.

Harp, J. A., M. E. Kehrli, Jr., D. J. Hurley, R. A. Wilson, and T. C. Boone. 1991. Numbers and percent of T lymphocytes in bovine peripheral blood during the periparturient period. Vet. Immunol. Immunopathol. 28:29-35.

Häusinger, D., F. Lang, and W. Gerok. 1994. Regulation of cell function by the cellular hydration state. Am. J. Physiol. 267:E343E355.

Huntington, G. B. 1984. Net absorption of glucose and nitrogenous compounds by lactating Holstein cows. J. Dairy Sci. 67:19191927.

Huntington, G. B., C. K. Reynolds, and B. H. Stroud. 1989. Techniques for measuring blood flow in splanchnic tissues of cattle. J. Dairy Sci. 72:1583-1595.

Jackson, A. A. 1991. The glycine story. Eur. Clin. Nutr. 45:59-65.

Johnson, M. M., and J. P. Peters. 1993. Technical note: An improved method to quantify nonesterified fatty acids in bovine plasma. J. Anim. Sci. 71:753-756.

Kehrli, M. E., B. J. Nonnecke, and J. A. Roth. 1989. Alterations in bovine lymphocyte function during the periparturient period. Am. J. Vet. Res. 50:215-220.

Kimura, K., J. P. Goff, M. E. Kehrli, and J. A. Harp. 1999. Phenotype analysis of peripheral blood mononuclear cells in periparturient dairy cows. J. Dairy Sci. 82:315-319.

Lacey, J. M., and D. W. Wilmore. 1990. Is glutamine a conditionally essential amino acid? Nutr. Rev. 48:297-309.

Lessard, M., N. Gagnon, D. L. Godson, and H. V. Petit. 2004. Influence of parturition and diets enriched in n-3 or n-6 polyunsaturated fatty acids on immune response of dairy cows during the transition period. J. Dairy Sci. 87:2197-2210.

Littell, R. C., G. A. Milliken, W. W. Stroup, and R. D. Wolfinger. 1996. SAS System for Mixed Models. SAS Institute Inc., Cary, NC.

Lobley, G. E., A. Connell, M. A. Lomax, D. S. Brown, E. Milne, A. G. Calder, and D. A. H. Farningham. 1995. Hepatic detoxification of ammonia in the ovine liver: Possible consequences for amino acid catabolism. Br. J. Nutr. 73:667-685.

Lobley, G. E., S. O. Hoskin, and C. J. McNeil. 2001. Glutamine in animal science and production. J. Nutr. 131:2525S-2531S.

Mallard, B. A., J. C. Dekkers, M. J. Ireland, K. E. Leslie, S. Sharif, C. L. Vankampen, L. Wagter, B. N. Wilkie. 1998. Alteration in immune responsiveness during the peripartum period and its ramification on dairy cow and calf health. J. Dairy Sci. 81:585595.

McDermott, R. H., and M. Butler. 1993. Uptake of glutamate, not glutamine synthetase, regulates adaptation of mammalian cells to glutamine-free medium. J. Cell Sci. 104:51-58.

McNeil, C. J. 2001. Glutamine and lymphocyte metabolism of sheep. Ph.D. Dissertation. University of Newcastle upon Tyne, Newcastle upon Tyne, UK.

Meijer, G. A. L., J. van der Meulen, J. G. M. Bakker, C. J. van der Koelen, and A. M. van Vuuren. 1995a. Free amino acids in plasma and muscle of high yielding dairy cows in early lactation. J. Dairy Sci. 78:1131-1141.

Meijer, G. A. L., H. de Visser, J. van der Meulen, C. J. van der Koelen, and A. Klop. 1995b. Effect of glutamine or propionate infused into the abomasum on milk yield, milk composition, nitrogen retention and net flux of amino acids across the udder of high yielding dairy cows. Pages $157-160$ in Proc. Seventh Symp. Protein Metabolism and Nutrition. A. F. Nunes, A. V. Portugal, J. P. Costa, and J. R. Ribeiro, ed. Estacoa Zootechnica National, Santerm, Portugal.

National Research Council. 2001. Nutrient Requirements of Dairy Cattle. 7th rev. ed. Natl. Acad. Sci., Washington, DC.

Newsholme, P. 2001. Why is L-glutamine metabolism important to cells of the immune system in health, postinjury, surgery or infection? J. Nutr. 131:2515S-2522S.

Perriello, G., N. Nurjhan, M. Stumvoll, A. Bucci, S. Welle, G. Dailey, D. M. Bier, I. Toft, T. G. Jenssen, and J. E. Gerich. 1997. Regulation of gluconeogenesis by glutamine in normal postabsorptive humans. Am. J. Physiol. 272:E437-E445.

Plaizier, J. C., J. P. Walton, and B. W. McBride. 2001. Effect of postruminal infusion of glutamine on plasma amino acids, milk yield and composition in lactating dairy cows. Can. J. Anim. Sci. 81:229-235.

Preisler, M. T., P. S. Weber, R. J. Tempelman, R. J. Erskine, H. Hunt, and J. L. Burton. 2000. Glucocorticoid receptor down-regulation in neutrophils of periparturient cows. Am. J. Vet. Res. 61:14-19.

Raggio, G., D. Pacheco, R. Berthiaume, G. E. Lobley, D. Pellerin, G. Allard, P. Dubreuil, and H. Lapierre. 2004. Effect of level of metabolizable protein on splanchnic flux of amino acids in lactating dairy cows. J. Dairy Sci. 87:3461-3472.

Reecy, J. M., J. E. Williams, M. S. Kerley, R. S. MacDonald, W. H. Thornton, Jr., and J. L. Davis. 1996. The effect of postruminal amino acid flow on muscle cell proliferation and protein turnover. J. Anim. Sci. 74:2158-2169.

Reeds, P. J., D. G. Burrin, B. Stoll, and F. Jahoor. 2000. Intestinal glutamate metabolism. J. Nutr. 130:978S-982S.

Reynolds, C. K., P. C. Aikman, B. Lupoli, D. J. Humphries, and D. E. Beever. 2003. Splanchnic metabolism of dairy cows during the transition from late gestation through early lactation. J. Dairy Sci. 86:1201-1217.

Rohde, T., D. A. Maclean, and B. Klarlund Pedersen. 1996. Glutamine, lymphocyte proliferation and cytokine production. Scand. J. Immunol. 44:648-650.

SAS Institute. 1999. SAS System for Mixed Models. SAS Institute, Cary, NC.

Schröder, M., G. Schäfer, and P. Schauder. 1990. Characterization of glutamine transport into resting and concanavalin A-stimulated peripheral human lymphocytes. J. Cell Physiol. 145:155-161.

Van Kampen, C., and B. A. Mallard. 1997. Effects of peripartum stress and health on circulating bovine lymphocyte subsets. Vet. Immunol. Immunopathol. 59:79-91.

Veenhuizen, J. J., J. K. Drackley, M. J. Richard, T. P. Sanderson, L. D. Miller, and J. W. Young. 1991. Metabolic changes in blood and liver during development and early treatment of experimental fatty liver and ketosis in cows. J. Dairy Sci. 74:4238-4253.

Vom Dahl, S., and D. Häusinger. 1996. Nutritional state and the swelling-induced inhibition of proteolysis in perfused rat liver. J. Nutr. 126:395-402.

Williamson, D. H., and J. Mellanby. 1974. D-(-)-3-Hydroxybutyrate. Page 1836 in Methods of Enzymatic Analysis. Vol. IV. H. U. Bergmeyer, ed. Academic Press, New York, NY.

Wu, G., and L. W. Greene. 1992. Glutamine and glucose metabolism in bovine blood lymphocytes. Comp. Biochem. Physiol. 103B:821-825. 